\title{
Evaluation of information transfer between Extension Agents and dairy producers in Pennsylvania
}

\author{
Carrie B. Nelson \\ West Virginia University
}

Follow this and additional works at: https://researchrepository.wvu.edu/etd

\section{Recommended Citation}

Nelson, Carrie B., "Evaluation of information transfer between Extension Agents and dairy producers in Pennsylvania" (2008). Graduate Theses, Dissertations, and Problem Reports. 2637.

https://researchrepository.wvu.edu/etd/2637

This Thesis is protected by copyright and/or related rights. It has been brought to you by the The Research Repository @ WVU with permission from the rights-holder(s). You are free to use this Thesis in any way that is permitted by the copyright and related rights legislation that applies to your use. For other uses you must obtain permission from the rights-holder(s) directly, unless additional rights are indicated by a Creative Commons license in the record and/ or on the work itself. This Thesis has been accepted for inclusion in WVU Graduate Theses, Dissertations, and Problem Reports collection by an authorized administrator of The Research Repository @ WVU. For more information, please contact researchrepository@mail.wvu.edu. 


\title{
Evaluation of Information Transfer Between Extension Agents and Dairy Producers in Pennsylvania
}

\author{
Carrie B. Nelson
}

Thesis submitted to the Davis College of Agriculture, Forestry and Consumer Sciences at West Virginia University in partial fulfillment of the requirements

for the degree of

Master of Science

in

Agriculture and Extension Education

Deborah A. Boone, Ph.D., Chair

Harry N. Boone, Jr., Ph.D.

Jean M. Woloshuk, Ed.D.

Division of Resource Management

Morgantown, West Virginia

2008

Key Words: Extension Agents, Dairy Producers, Information Transfer, Extension 


\begin{abstract}
Evaluation of Information Transfer Between Extension Agents

and Dairy Producers in Pennsylvania
\end{abstract}

Carrie B. Nelson

The purpose of this study was to determine how information from Extension Agents was being disseminated to dairy producers in Pennsylvania in areas of program advertisement and teaching methods. It also sought to determine if Extension Agents are reaching special populations of producers (e.g. Amish, Hispanic, disabled) in their areas. A descriptive research design was used to collect the data for this study. The target population was all dairy producers in Pennsylvania and the Extension Agents that serve these producers. The study found that Extension Agents and dairy producers agree on advertisement methods but disagree on teaching methods. Furthermore, the types of programs offered by Extension Agents differ from the types desired by dairy producers. Extension Agents report they are adjusting programs to accommodate Amish producers, but not necessarily Hispanic or disabled producers. 


\title{
DEDICATION
}

This thesis is dedicated to the important people in my life who have always been supportive of everything I have done:

\author{
Mom and Dad \\ Chad and Lory \\ Dale
}




\section{ACKNOWLEDGEMENTS}

Obtaining my master's degree and finishing my thesis has taken a lot of work with a help from many people. I would like to thank those who have helped me to accomplish my goal.

To my parents, Barb and Ken: Thank you for all of your support (both mentally and financially) through the year and for keeping me on track to getting my Master’s finished. Mom, as always, you were right!

To my brother and sister-in-law, Chad and Lory: Thank you for being there for me through it all. This includes anything from hanging out on the weekends to Lory giving me teaching advice and telling me crazy stories about her teaching experiences.

To my fiancé, Dale: Thank you for always being just a lengthy phone call away to listen to me ramble on endlessly about exciting or frustrating things going on at school.

I would like to thank my committee for helping me to accomplish my goals:

To Dr. Debby Boone: I appreciate everything that you have done for me while I have been in graduate school including answering the thousands of questions that I had everyday about everything. Thank you for providing me with this opportunity.

To Dr. Harry Boone: You have helped me with so many things from starting to write my thesis to analyzing my data. Without you, I never would have 
accomplished what I have. Also, thank you for the opportunity to gain experience by teaching AGEE 101.

To Dr. Jean Woloshuk: Thank you for being a part of my committee and for your expertise in helping me to make my instrument pertain more to dairy producers.

To my friend, Jen: Thank you for giving me the opportunity to escape my school work and act as your assistant at the farm.

To Jeannine: Thank you for taking such good care of Petri and Susie while I have been at school. 


\section{TABLE OF CONTENTS}

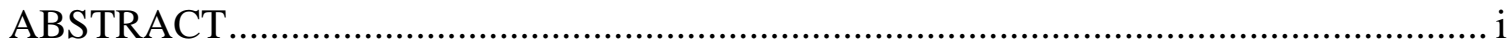

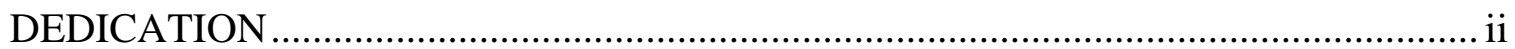

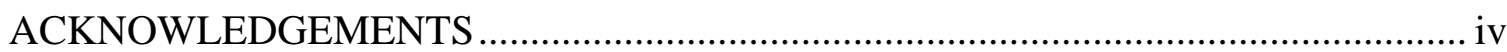

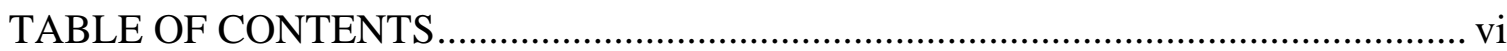

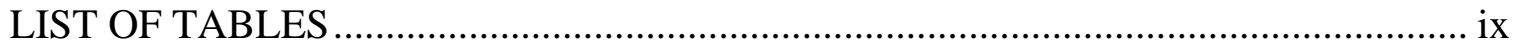

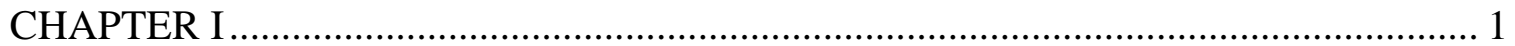

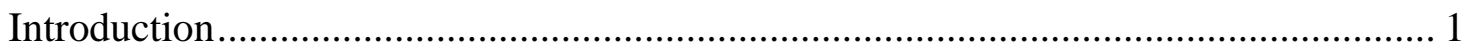

Purpose and Objectives .................................................................................. 3

Research Questions..................................................................................... 3

Limitations of this Study ............................................................................ 4

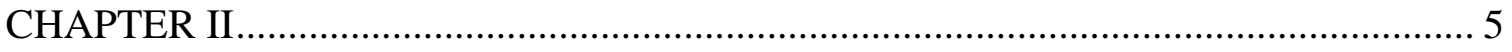

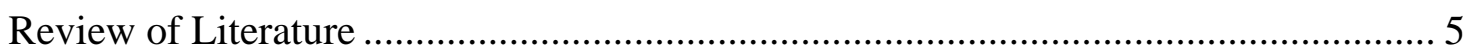

Advertisement for Programs ............................................................................ 5

Teaching Methods Utilized During Programs..................................................... 6

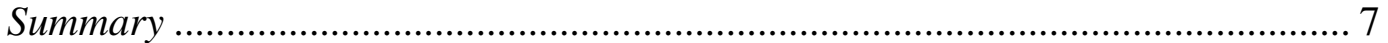

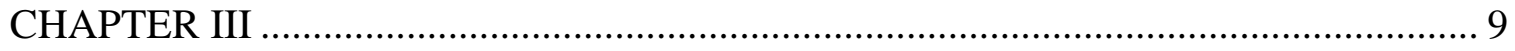

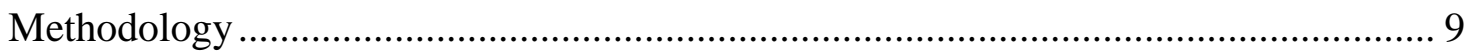

Purpose and Objectives .............................................................................. 9

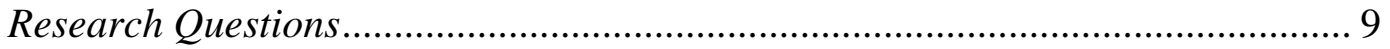

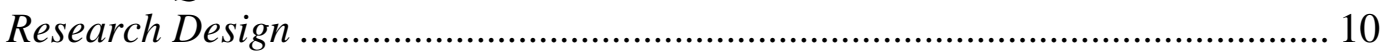

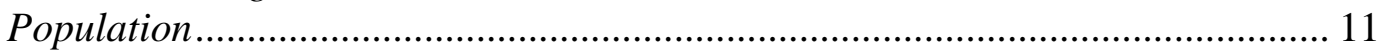

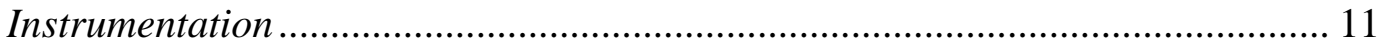

Validity of the Instrument ............................................................................... 12

Reliability of the Instrument........................................................................ 12

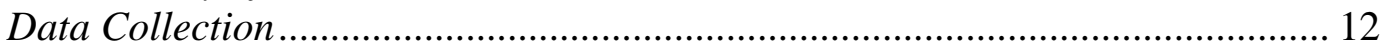

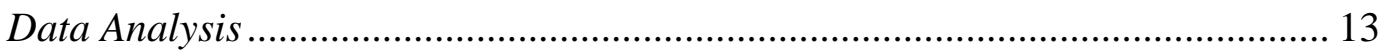

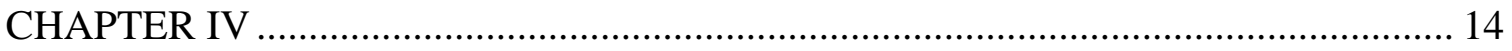

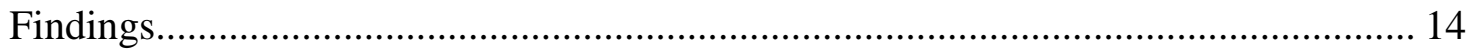

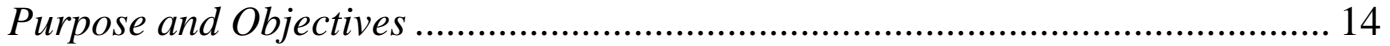

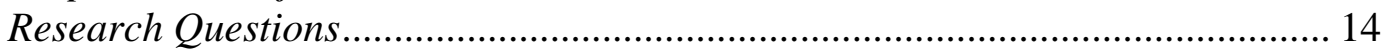

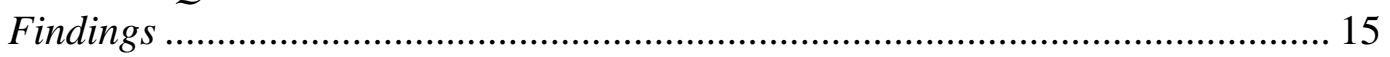

Extension Agents .............................................................................................. 15

Extension Agents' Attitudes Towards Their Extension Programs........................ 15

Extension Agents' Methods of Advertisement for Programs ................................. 17

Teaching Methods Used During Dairy Programs by Extension Agents .............. 20

Dairy Programs Offered by Extension Agents..................................................... 22

Amish, Hispanic and Disabled Producers in the Extension Agents'

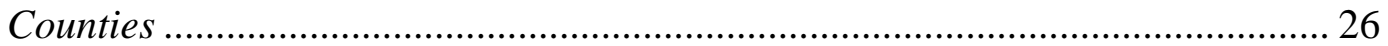

Extension Agents' Opinions of Preferred Information Sources Used by

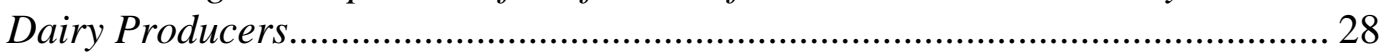

Programs Offered per Year ................................................................................ 30

Extension Agents' Views on Dairy Producers' Demographics ............................ 30

Extension Agents' Additional Comments............................................................ 31

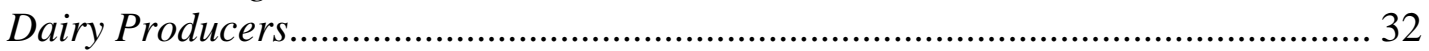


Dairy Producers' Attitudes Toward Extension Dairy Programs ......................... 32

Dairy Producers' Preferred Methods of Advertisement for Dairy

Programs. 34

Dairy Producers' Preferred Teaching Methods Used During Dairy

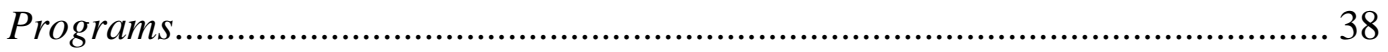

Programs Preferred by Dairy Producers ......................................................... 42

Dairy Producers' Preferred Sources of Dairy Production Information .............. 46

Number of Programs Attended by Dairy Producers Each Year .......................... 47

Dairy Producer Demographic Information ........................................................ 48

Dairy Producers' Additional Comments ........................................................... 49

Comparison of Extension Agents and Dairy Producers in Pennsylvania ............ 49

Comparison of Attitudes Toward Attendance at Extension Programs .................. 50

Comparison of Attitudes Toward the Use of Mail as an Advertisement

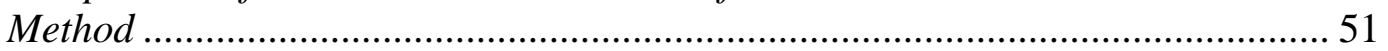

Comparison of Attitudes Toward the Use of Pamphlets as an

Advertisement Method ............................................................................................. 52

Comparison of Attitudes Toward the Use of Flyers as an Advertisement

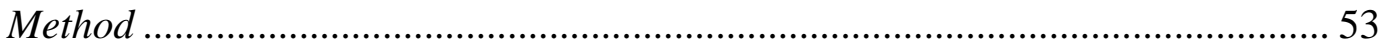

Comparison of Attitudes Toward the Use of Word of Mouth as an

Advertisement Method ........................................................................................... 54

Comparison of Attitudes Toward the Use of Exhibits as an Advertisement

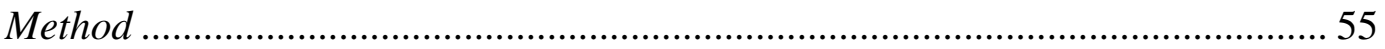

Comparison of Attitudes Toward the Use of Radio as an Advertisement

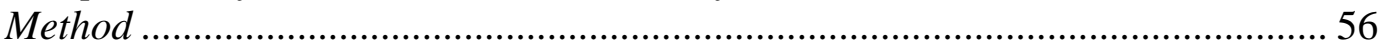

Comparison of Attitudes Toward the Use of Television as an

Advertisement Method ............................................................................................. 57

Comparison of Attitudes Toward the Use of Books as a Teaching Method ......... 58

Comparison of the Offering of and the Desire for Dairy Nutrition

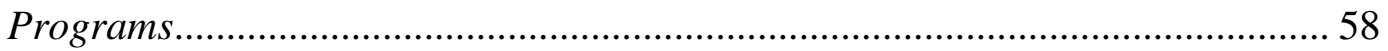

Comparison of the Offering of and Desire for Heifer Management

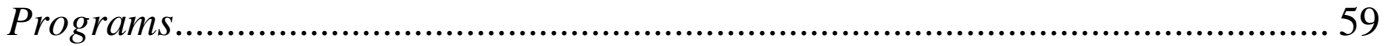

Comparison of Offering of and Desire for Forage Production Programs........... 60

Comparison of Offering of and Desire for Milking Management Programs ....... 61

Comparison of Offerings of and Desire for Herd Health Programs .................... 62

Comparison of Offerings of and Desire for Reproduction Programs ................... 63

Comparison of Offerings of and Desire for Nutrient Management

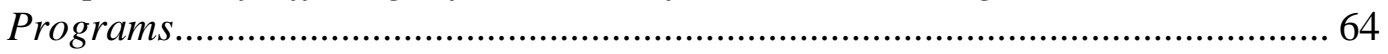

Comparison of Offerings of and Desire for Dairy Quality Assurance

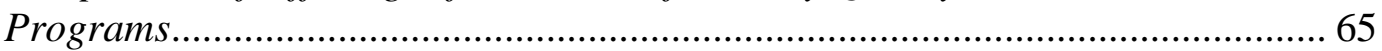

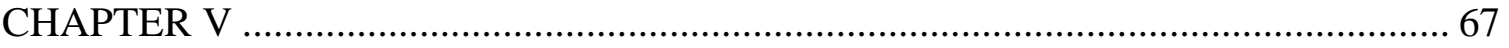

Summary, Conclusions, and Recommendations................................................... 67

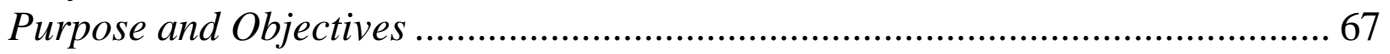

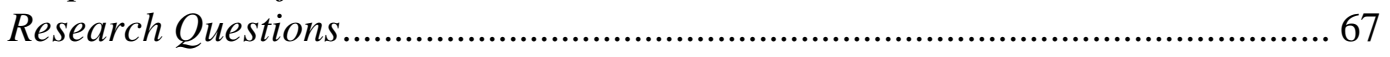

Summary ................................................................................................ 68

Research Question One - "How do Extension Agents in Pennsylvania

Advertise for their Programs? " .......................................................................... 68 
Research Question Two - "How do Dairy Producers in Pennsylvania Prefer to Learn about Extension Programs?" 68

Research Question Three - "What Methods do Extension Agents use to

Teach their Programs?"

Research Question Four - "What Teaching Methods do Dairy Producers

Prefer be Used during Programs?”

Research Question 5 - "Are Pennsylvania Extension Agents connecting

with Dairy Producers in their County through Advertising and

Information Transfer During Programs as Well as Types of Programs

Offered?"

Research Question Six - "Are Extension Agents Targeting Programs to the Special Populations (e.g. Amish, Hispanic, Disabled) in their County and how are they Making Adjustments to Accommodate them in their Programs?"

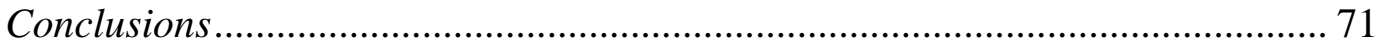

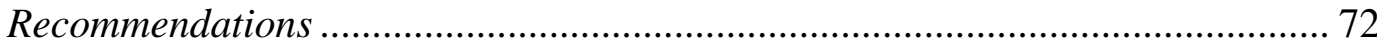

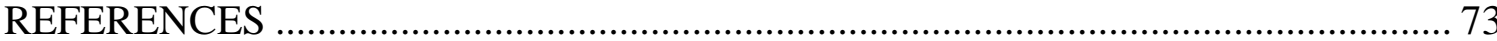

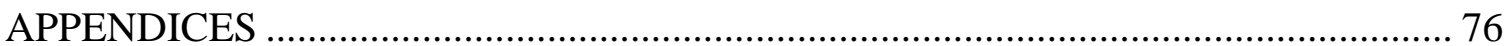

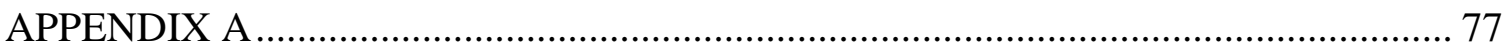

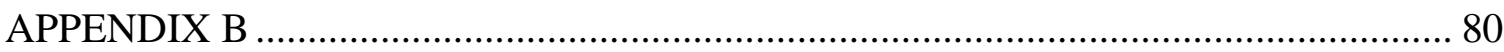

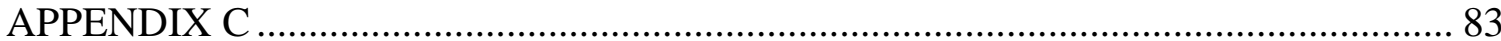

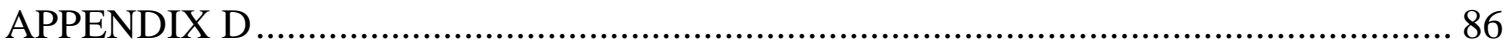

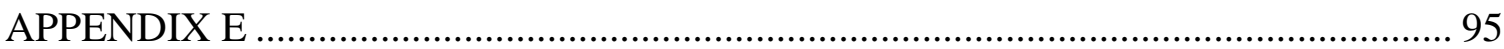

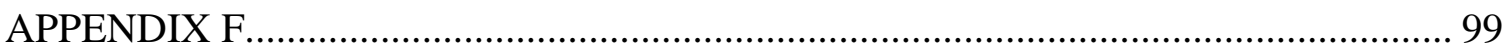

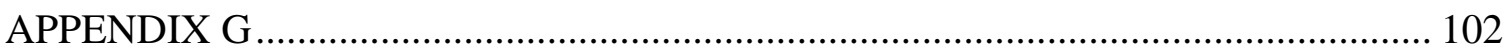

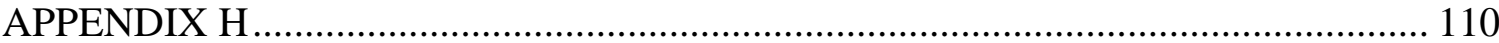

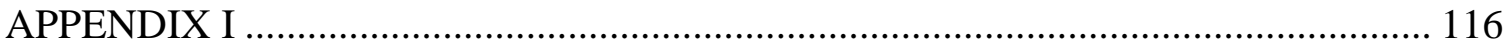

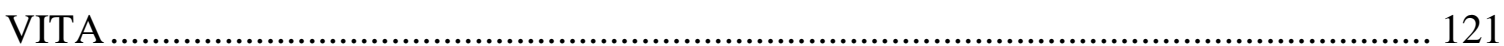




\section{LIST OF TABLES}

Table Title

1 Extension Agents' Attitudes Toward Their Dairy Programs .17

2 Methods of Advertisement Used for Dairy Programs by Extension Agents.........19

3 Teaching Methods Used During Dairy Programs by Extension Agents..............22

$4 \quad$ Dairy Programs Offered by Extension Agents ................................................25

5 Amish, Hispanic and Disabled Populations Within the Extension Agents' Counties

6 Extension Agents' Opinion of Preferred Information Sources Used by Dairy Producers.

$7 \quad$ Extension Agents' Opinions of Preferred Information Sources Used by Dairy Producers.

$8 \quad$ Number of Programs Offered by Extension Agents per Year .30

9 Extension Agents' Opinions of Average Dairy Herd Size in Their Counties

10 Extension Agents' Opinions of Average Age of Dairy Producers in Their Counties

11 Dairy Producers’ Attitudes Toward Extension Dairy Programs....

12 Dairy Producers' Preferred Methods of Advertisement for Dairy Programs.

13 Dairy Producers' Preferred Teaching Methods Used During Dairy

Programs.

14 Dairy Producers’ Preferred Program Topics .45

15 Dairy Producers' Preferred Source of Dairy Production Information .46

16 Dairy Producers' Preferred Source of Dairy Production Information .47

17 Number of Programs Attended by Dairy Producers per Year .

18 Dairy Cattle Herd Size of Dairy Producers .48

19 Ages of Dairy Producers

20 Comparison of Agents and Producers Toward Attendance at Extension Programs.

21 Comparison of Agents and Producers Toward Use of Mail to Advertise for Programs.

22 Comparison of Agents and Producers Toward the Use of Pamphlets to Advertise for Programs. 
23 Comparison of Agents and Producers on Toward Using Flyers to Advertise for Programs........................................................................54

24 Comparison of Agents and Producers Toward the Use of Word of Mouth to Advertise for Programs......................................................................55

25 Comparison of Agents and Producers Toward on Using Exhibits to Advertise for Programs.............................................................................56

26 Comparison of Agents and Producers Toward Using Radio to Advertise

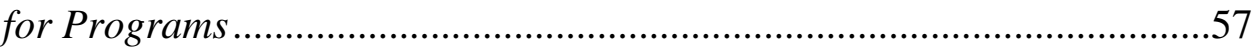

27 Comparison of Agents and Producers Toward Using Television to Advertise for Programs...........................................................................5

28 Comparison of Agents and Producers Toward the Use of Books as a Teaching Method .58

29 Comparison of Agents and Producers on the Topic of Dairy Nutrition Programs.

30 Comparison of Agents and Producers on the Topic of Heifer Management Programs.

31 Comparison of Agents and Producers on the Topic of Forage Production Programs.

32 Comparison of Agents and Producers on the Topic of Milking Management Programs.

33 Comparison of Agents and Producers on the Topic of Herd Health Programs.

34 Comparison of Agents and Producers on the Topic of Reproduction Management Programs.

35 Comparison of Agents and Producers on the Topic of Nutrient Management Programs.

36 Comparison of Agents and Producers on the Topic of Dairy Quality Assurance Programs .66 


\section{CHAPTER I}

Introduction

Pennsylvania is the number five producer of milk in the United States (National Agricultural Statistic Service, 2006) with 9,146 farms that produce milk and dairy products (2002 Census of Agriculture). Dairy production is impacted by various factors including nutrition, herd health and milking management. In an information rich society there are many people that the producer can turn to for answers to questions they have regarding certain areas of production. Resource people may include the veterinarian, the feed sales person or a trusted neighbor. One source that has been available to producers for a number of years is the County Extension Agent.

In 1914 the Cooperative Extension Service (CES) was established by the SmithLever Act (Seevers, Graham \& Conklin, 2007). This service is a collaboration of three distinct partners: the United States Department of Agriculture (USDA), the Cooperative State Research, Education and Extension Service (CSREES) and each states land grant university (Seevers et al., 2007). The mission of the CES, established in 1914, is “...To aid in diffusing among the people of the United States useful and practical information on subjects relating to agriculture and home economics, and to encourage the application of the same.” (Smith-Lever Act, 1990, sec. 1).

Extension Agents in Pennsylvania are available to assist people with agriculture related problems including dairy production. As technology increases in the world Extension Agents will continue to adapt how they advertise and implement programs. Neehouse (2005) found that West Virginia Extension Agent's third highest preference to disseminate information was via the Internet. "Implications suggest that extension should 
avoid moving too rapidly into newer, impersonal forms of communications to meet informational needs of it’s agricultural audiences,” (Richardson \& Mustian, 1988, p 1). As the Extension Agent looks towards the future, they cannot overlook the clientele who for whatever reason have shunned technological advances.

The population of dairy producers in Pennsylvania is very diverse. The 2002 Census of Agriculture indicates that the average age of a Pennsylvania farmer was 53.1 years old. There were 349 farms in Pennsylvania that had Spanish, Hispanic or Latino operators which is $3.82 \%$ of all dairy farms. In addition to the Spanish there is a large population of Amish in Pennsylvania. The Amish (2007) stated that, "The oldest, richest and third largest group [of Amish] is the settlement centering in Lancaster County” (p. 1).

Using the Internet is the third highest form of dissemination of information among Extension Agents in West Virginia (Neehouse, 2005) while a Michigan State University study found that only $10 \%$ of farmers surveyed obtained information from the Internet (which was up from the 1.4\% in 1996) (Suvedi \& Campo, 2000). Of the 349 Spanish, Hispanic or Latino farms only 89 were using computers for business and only one-third of these 89 report having Internet access (2002 Census of Agriculture, 2002). According to available literature on the Amish, “...most elements from mainstream society—such as electricity throughout their homes, TV, computers and modern tractors-are considered to be tempting elements from an "outside world" that could lead them away from their close knit community...” (The Amish and Technology, 2008, para. 1)

With the diverse farm populations in Pennsylvania how are Extension Agents connecting with each of the producers? Do Extension Agents communicate with and offer programs for their various clientele that meets the needs and preferences of the 
dairy producers? Understanding clientele preferences for information transfer will assist Pennsylvania Extension Agents in developing better communication methods, thereby increasing program attendance as well as the adoption of innovative practices.

\section{Purpose and Objectives}

The purpose of this study was to determine if information from Extension Agents is getting to the dairy producers through appropriate advertising of programs as well as the information disseminated during programs. In addition what are Extension Agents doing to reach special populations (e.g. Amish, Hispanic, disabled) of dairy producers in their county?

The primary objective of this study was to compare the services Extension Agents are providing within a county with the services producers of the county would like to have. The research focused on areas of advertising for programs, information transfer during programs, and program offerings.

\section{Research Questions}

1. How do Extension Agents in Pennsylvania advertise their extension programs?

2. How do dairy producers in Pennsylvania prefer to learn about extension programs?

3. What methods do Pennsylvania Extension Agents use to teach their programs?

4. What teaching methods do Pennsylvania dairy producers prefer to be used during programs?

5. Are Pennsylvania Extension Agents connecting with dairy producers in their county through advertising and information transfer during programs as well as types of programs offered? 
6. Are Pennsylvania Extension Agents targeting programs to the special populations (e.g. Amish, Hispanic, disabled) in their county and how are they making adjustments to accommodate them in their programs?

\section{Limitations of this Study}

This study was limited to dairy producers within the Lancaster DHIA Annual Report. It was also limited to Extension Agents that served Pennsylvania counties where targeted dairy producers resided. It did not include other Extension Agents or dairy producers. 


\section{CHAPTER II}

\section{Review of Literature}

The Cooperative Extension Service (CES) is one of the largest organizations to educate adults in the world (Seevers, Graham, \& Conklin, 2007). There are many adults served by the CES, including dairy producers. The National Languages and Literacy Institute of Australia (1999) found that adults seek educational opportunities for many reasons. Some of these reasons include: to achieve goals, to make up for lack of previous education, for their own development or to do better at a job.

\section{Advertisement for Programs}

The first thing that must happen in order for a CES program to be a success is for the clientele to become aware of the CES. Warner (1996) found that only 45 percent of the 1,048 people in a 1995 survey were aware of the Cooperative Extension Service. This was up five percent from 1982 and, "every farm resident in the 1995 sample was aware of Extension.” Furthermore, Rexroad (2002) found that most people became aware of programs first by participating in other extension programs (23\%) followed by referrals by friends (18.9\%) and newspaper articles (13.5\%). One of the least popular ways people became aware of the programs were through Extension Internet sites (1.4\%).

There are three steps involved in developing an Extension program: planning, design and implementation and evaluation (Seevers et al, 2007). The planning process should include how a program will be marketed. Nehiley (2001) developed a four step plan to marketing Extension programs. The plan is to (1) conduct an audience inventory, (2) define your goals and specify your objectives, (3) decide on the nature of your message and (4) decide on the appropriate media. The Extension Agent needs to, "Use 
the media that works with that targeted subgroup of the population.” (Step Four: Decide on Appropriate Media, para. 1).

The average age of a farmer in Pennsylvania is 53.1 years old (2002 Census of Agriculture). Iddings and Apps (1990) focused on how producers felt about computers and found that many farmers believe, “You can’t teach an old dog new tricks.” and "I’m too old to learn.” (Age, para. 1) This shows the need to implement methods of advertisement that do not just involve using the latest technologies.

Neehouse (2005) found that most of the Extension Agents in West Virginia prefer writing in newspapers to disseminate information, followed by using a bulletin or newsletter. The third most desired method by which Extension Agents prefer to disseminate information was using the Internet.

\section{Teaching Methods Utilized During Programs}

New practices are taught with the hopes that participants will apply what they have learned. Peters (1998) found that there were four important factors that lead to the adoption of a practice which included mutual trust, credibility of information, actual farm demonstrations and amount of communication. In order for something to be adopted the Extension Agent must contribute to these factors.

Gamon, Harrold and Creswell (1994) looked at rates of acceptance of new practices. They found, "there were no significant differences between the farmers who attended and those who did not [attend programs]. Also, there were no significant differences for level of information and adoption practices before and after the conferences” (Gamon, Harrold \& Creswell, 1994, p. 41). Getting the producer to the 
program does not guarantee an accepted practice. This is why it is crucial to use producer preferred teaching methods.

Chizari, Mostafa \& Linder (1998) found that Extension Agents perceived result demonstrations, method demonstrations, and formal group meetings were the most effective extension education teaching methods. On the contrary, Richardson and Mustian (1988) found that $90.7 \%$ of dairy producers in North Carolina considered the use of newsletters important, followed by farm visits (83.3\%) and meetings (79.6\%). In addition, "Information delivery techniques such as teleconferencing, video tapes, audio cassettes, cable television, and home study courses were rated quite low” (Richardson \& Mustian, 1988, p. 1).

According to Riesenberg \& Gor (1989), desired teaching methods vary because of the age of the farmer, size of the farm and educational status of the farmer. It was found that young farmers, as well as college educated farmers, prefer to use computers to learn. Farmers with large acreage benefit most from publications. Brown (2003) found that, “Age, educational level, and motivation influence each student's learning so that what was once preferred may no longer be the student's current preferred learning style.” This emphasizes the need to research who will be attending the programs so that the most effective delivery methods can be utilized to improve adoption.

\section{Summary}

Studies relating to the research questions posed for this study vary in age. Research on dairy producer's preferences on delivery methods has been conducted over several years, while the research that relates to how Extension Agents prefer to disseminate information has been conducted more recently. No studies were found that 
linked dairy producer's preferences to Extension Agent's preferences. Therefore it is necessary to conduct this study to determine if Extension Agents and dairy producers are connecting with their preferred advertising and teaching methods. 


\section{CHAPTER III}

\section{Methodology}

\section{Purpose and Objectives}

The purpose of this study was to determine if information from Extension Agents is getting to the dairy producers, through appropriate advertising of programs as well as the information disseminated during programs. In addition what are Extension Agents doing to reach the special populations (e.g. Amish, Hispanic, disabled) of dairy producers in their county?

The primary objective of this study was to compare the services Extension Agents are providing within a county with the services producers of the county would like to have. The research focused on areas of advertising for programs, information transfer during programs, and program offerings.

\section{Research Questions}

1. How do Extension Agents in Pennsylvania advertise their extension programs?

2. How do dairy producers in Pennsylvania prefer to learn about extension programs?

3. What methods do Pennsylvania Extension Agents use to teach their programs?

4. What teaching methods do Pennsylvania dairy producers prefer to be used during programs?

5. Are Pennsylvania Extension Agents connecting with dairy producers in their county through advertising and information transfer during programs as well as types of programs offered? 
6. Are Pennsylvania Extension Agents targeting programs to the special populations (e.g. Amish, Hispanic, disabled) in their county and how are they making adjustment to accommodate them in their programs?

\section{Research Design}

Descriptive research, in the form of a survey of intangibles, was used to evaluate the above mentioned questions. "Surveys permit the researcher to summarize the characteristics of different groups or to measure their attitudes and opinions toward some issue,” (Ary, Jacobs, Razavieh \& Sorensen, 2006 p 31). By using a mailed questionnaire, a sample of the target population was able to be reached regardless of location.

There are five errors which exist with survey research that need to be controlled. To avoid frame error official lists of DHIA producers in Pennsylvania were used. To avoid sample error a random sample of all dairy producers from the annual report was taken and the Extension Agents were purposely chosen based on the location of the producers selected.

Selection error was avoided by going through the annual report to make sure each producer appeared only once and that agents that worked in more than one county were sent only one survey. Measurement error was controlled by making sure that the instrument was valid and reliable.

The potential for non-response error was identified by comparing the early respondents to the late respondents. For dairy producers Pearson Chi-Square was used to determine if there were differences in three variables. The variables included how many dairy extension programs were attended per year, how many head of dairy cattle were owned by the producers and the age range of the producers. Chi-Square resulted in no 
significance in each of the three variables so generalizations for this segment of the study could be made back to the entire population of dairy producers. For Extension Agents it was assumed that the first six questions in the instrument were a good representation of knowledge of dairy programs. Early and late respondents were compared on the first six questions finding no significance. The findings of this study could be generalized back to the entire population.

\section{Population}

The target population for this research study was all dairy producers and dairy Extension Agents in Pennsylvania. The accessible population of dairy producers was the producers listed in the 2005-2006 Lancaster DHIA Annual Report ( $\mathrm{N}=1000)$. The total sample size of dairy producers $(\mathrm{n}=278)$ was determined by using the Krejcie and Morgan table (1970). The accessible population of dairy Extension Agents were all agents responsible for dairy programming who serve in the counties where the selected producers resided $(\mathrm{N}=31)$. Following the two mailings, four surveys (three producers and one agent) were returned as undeliverable.

\section{Instrumentation}

Two different and separate surveys were sent to dairy producers and dairy Extension Agents in Pennsylvania. The survey type used was a survey of intangibles. This type was used because attitudes were to be determined from a sample of the population. It consisted of Likert-type questions with six responses available. The responses included strongly agree, moderately agree, agree, disagree, moderately disagree and strongly disagree. Neutral was omitted so that producers and agents had to 
give an opinion on each topic. This type of question was chosen because it is a way to determine attitudes on a subject (Ary et al., 2006).

The dairy producer survey consisted of questions evaluating their attitudes toward their Extension Agent, their preferred advertising methods for programs, their preferred teaching methods for programs and their preferred type of programs. The Extension Agent survey consisted of questions evaluating their attitudes toward how they serve their county, how they advertise for programs, the teaching methods they utilize during programs and what programs they offer. In addition to the Likert-type questions, the instrument included ranking, single response questions and demographic type questions.

Validity of the Instrument. The instrument was presented to faculty members in Agricultural and Extension Education at West Virginia University. The faculty determined that the instrument had face and content validity.

Reliability of the Instrument. The reliability of the instrument was established using the entire data set and the Statistical Package for Social Sciences’ (SPSS). The Likert-type items were tested for reliability using the split-half statistic coefficient. The unequal-length Spearman-Brown value was found to be .9742 for the Extension Agent instrument and .8456 for the dairy producer instrument making reliability of the instrument exemplary (J.P Robinson, P.R. Shaver, \& L.S. Wrightsman 1991).

\section{Data Collection}

To collect data, Dillman’s (2007) tailored design method was used. A packet was mailed on January 3, 2008 that contained a cover letter explaining the purpose of the study, the instrument, a pre-paid self addressed envelope and a small token of appreciation (a United Dairy magnet for producers and a ruler for agents). Participants 
were given a deadline of January 18, 2008. A second mailing was sent to all nonrespondents on January 25, 2008. This packet consisted of a second cover letter, a second survey and a pre-paid self addressed envelope. A deadline of February 10, 2008 was given for the second mailing. A post card was then sent to all dairy producers who did not respond and an email was sent to all Extension agents that did not respond asking to please complete the survey and return by February 15, 2008.

Data Analysis

Each respondent was given a code in order to track non-respondents. The code and key was later destroyed to keep individual responses confidential. Data were first entered into an Excel spreadsheet with comments to open ended questions being entered in their entirety. SPSS was then used to analyze the data. Frequency tables were developed for all of the data on both instruments. The dairy producers and Extension Agents were then compared using the t-test for Equality of Means. 


\section{CHAPTER IV}

\section{Findings}

\section{Purpose and Objectives}

The purpose of this study was to determine if information from Extension Agents is getting to the dairy producers, through appropriate advertising of programs as well as the information disseminated during programs. In addition what are Extension Agents

doing to reach the special populations (e.g. Amish, Hispanic, disabled) of dairy producers in their county?

The primary objective of this study was to compare the services Extension Agents are providing within a county with the services producers of the county would like to have. The research focused on areas of advertising for programs, information transfer during programs, and program offerings.

\section{Research Questions}

1. How do Extension Agents in Pennsylvania advertise their extension programs?

2. How do dairy producers in Pennsylvania prefer to learn about extension programs?

3. What methods do Pennsylvania Extension Agents use to teach their programs?

4. What teaching methods do Pennsylvania dairy producers prefer to be used during programs?

5. Are Pennsylvania Extension Agents connecting with dairy producers in their county through advertising and information transfer during programs as well as types of programs offered? 
6. Are Pennsylvania Extension Agents targeting programs to the special populations (e.g. Amish, Hispanic, disabled) in their county and how are they making adjustment to accommodate them in their programs?

\section{Findings}

The target population for this study consisted of all dairy producers and Extension Agents in Pennsylvania. The accessible population of dairy producers included all dairy producers in the Lancaster County DHIA $(\mathrm{n}=1000)$ and the accessible population of Extension Agents was the entire population of agents serving the dairy producer population identified in segment one. A sample of 277 dairy producers was randomly selected. Three were returned as undeliverable making the sample size 274 producers. Of the 274 questionnaires, 113 (41.24\%) were returned. A purposeful sample of Extension Agents $(n=31)$ was selected based on who served in the counties where the dairy producers reside. One position was vacant making the total sample size of Extension Agents 30. Of the 30 questionnaires, 24 (80\%) were returned.

\section{Extension Agents}

\section{Extension Agents’ Attitudes Towards Their Extension Programs}

When asked about their dairy programs, 19 Extension Agents (86.3\%) were in some form of agreement that they offered dairy related programs. Eleven Extension Agents (50\%) strongly agreed, one respondent (4.5\%) moderately agreed and seven (31.8\%) agreed that they offered dairy programs. Three of the agents (14.5) were in some form of disagreement where one agent (4.5\%) strongly disagreed, one agent (4.5\%) moderately disagreed and one (4.5\%) disagreed that they offered dairy programs (see Table 1). 
Sixteen of the extension agents (72.7\%) were in some form of agreement when asked if they were able to answer most dairy questions with six (27.3\%) who strongly agreed. Four (18.2\%) moderately agreed and six (27.3\%) agreed to being able to answer most dairy questions. Of the 22 respondents six (27.2\%) expressed some degree of disagreement when asked if they were able to answer dairy questions where most of the respondents (18.2\%) disagreed and two respondents (9.1\%) moderately disagreed (see Table 1).

Of the 22 respondents, all (100\%) were in agreement when asked if they returned phone calls and emails quickly. Ten respondents (45.5\%) strongly agreed to returning phone calls and emails quickly. Three (13.6\%) moderately agreed and nine (40.9\%) agreed to returning phone calls and emails quickly (see Table 1).

Seven of the respondents (33.3\%) strongly agreed when asked if they were a reliable source for dairy questions. Five (23.8\%) moderately agreed and five (23.8\%) agreed to being a reliable source for dairy questions. Four respondents $(19.1 \%)$ were in some sort of disagreement when asked if they were a reliable source for dairy questions where one agent (4.8\%) moderately disagreed and three (14.3\%) disagreed (see Table 1).

Eleven respondents (52.4\%) were in some form of disagreement when asked if producers attended their programs. One respondent (4.8\%) strongly disagreed with this statement while one (4.8\%) moderately disagreed and nine (42.9\%) disagreed. Ten of the respondents (47.6\%) were in some sort of agreement including four (19\%) who moderately agreed and six (28.6\%) who agreed when asked if producers attended their programs (see Table 1). 
Seventeen of the respondents (80.9\%) were in some sort of agreement when asked if producers accepted what they were taught during programs. Of these 17 respondents one (4.8\%) strongly agreed, four (19\%) moderately agreed and 12 (57.1\%) agreed. Four respondents (9.1\%) were in some form of disagreement where one (4.8\%) moderately disagreed and three (14.3\%) disagreed when asked if producers accepted what they were taught during programs (see Table 1).

Table 1

Extension Agents’ Attitudes Toward Their Dairy Programs

\begin{tabular}{|c|c|c|c|c|c|c|c|c|c|c|c|c|}
\hline & \multicolumn{2}{|c|}{$\begin{array}{l}\text { Strongly } \\
\text { Disagree }\end{array}$} & \multicolumn{2}{|c|}{$\begin{array}{l}\text { Moderately } \\
\text { Disagree }\end{array}$} & \multicolumn{2}{|c|}{ Disagree } & \multicolumn{2}{|c|}{ Agree } & \multicolumn{2}{|c|}{$\begin{array}{c}\text { Moderately } \\
\text { Agree }\end{array}$} & \multicolumn{2}{|c|}{$\begin{array}{l}\text { Strongly } \\
\text { Agree }\end{array}$} \\
\hline & $n$ & $\%$ & $n$ & $\%$ & $n$ & $\%$ & $n$ & $\%$ & $n$ & $\%$ & $n$ & $\%$ \\
\hline $\begin{array}{l}\text { I offer programs in } \\
\text { dairy production }\end{array}$ & 1.0 & 4.5 & 1.0 & 4.5 & 1.0 & 4.5 & 7.0 & 31.8 & 1.0 & 4.5 & 11.0 & 50.0 \\
\hline $\begin{array}{l}\text { I am able to answer } \\
\text { most questions }\end{array}$ & 0.0 & 0.0 & 2.0 & 9.1 & 4.0 & 18.2 & 6.0 & 27.3 & 4.0 & 18.2 & 6.0 & 27.3 \\
\hline $\begin{array}{l}\text { I return calls and } \\
\text { emails quickly }\end{array}$ & 0.0 & 0.0 & 0.0 & 0.0 & 0.0 & 0.0 & 9.0 & 40.9 & 3.0 & 13.6 & 10.0 & 45.5 \\
\hline $\begin{array}{l}\text { I am a reliable } \\
\text { source for dairy } \\
\text { questions }\end{array}$ & 0.0 & 0.0 & 1.0 & 4.8 & 3.0 & 14.3 & 5.0 & 23.8 & 5.0 & 23.8 & 7.0 & 33.3 \\
\hline $\begin{array}{l}\text { Producers attend } \\
\text { programs }\end{array}$ & 1.0 & 4.8 & 1.0 & 4.8 & 9.0 & 42.9 & 6.0 & 28.6 & 4.0 & 19.0 & 0.0 & 0.0 \\
\hline $\begin{array}{l}\text { Teachings are } \\
\text { readily accepted }\end{array}$ & 0.0 & 0.0 & 1.0 & 4.8 & 3.0 & 14.3 & 12.0 & 57.1 & 4.0 & 19.0 & 1.0 & 4.8 \\
\hline
\end{tabular}

Extension Agents’ Methods of Advertisement for Programs

Extension Agents were asked to indicate what methods of advertisement they used to promote dairy programs in their county. Fourteen respondents (73.7\%) were in 
agreement that they used email as an advertisement method. Of these respondents four (21.1\%) strongly agreed, one (5.3\%) moderately agreed and nine (47.4\%) agreed. Three respondents (15.8\%) disagreed to using email as an advertisement method and two respondents (10.5\%) moderately disagreed. All 20 respondents (100\%) were in some form of agreement when asked if they use mail as an advertisement method. Fifteen respondents (75\%) strongly agreed and five (25\%) agreed (see Table 2).

All respondents (100\%) were in agreement that they used pamphlets as an advertisement method. Thirteen of the respondents (65\%) strongly agreed to using pamphlets, two (10\%) moderately agreed and five (25\%) agreed. All 20 respondents (100\%) were in agreement that they used flyers as an advertisement method. Twelve of the respondents (60\%) strongly agreed to using flyers, three (15\%) moderately agreed and five (25\%) agreed (see Table 2).

Six respondents (30\%) strongly agreed when asked if they use word of mouth as a method of advertisement. Five (25\%) moderately agreed and eight respondents (40\%) agreed to using word of mouth as a method of advertisement. One respondent (5\%) disagreed to using word of mouth (see Table 2). When asked if they use exhibits as a form of advertisement one (5.3\%) strongly agreed and six (31.6\%) agreed. One respondent (5.3\%) strongly disagreed to using exhibits as a form of advertisement. Two respondents (10.5\%) moderately disagreed and nine (47.4\%) disagreed (see Table 2).

Seventeen respondents (89.5\%) were in some form of disagreement when asked if they used radio as an advertisement method where five (26.3\%) strongly disagreed and twelve (63.2\%) disagreed. Only two respondents (10.6\%) agreed they used radio as an 
advertisement method, one respondent (5.3\%) strongly agreed and one (5.3\%) agreed (see Table 2).

Table 2

Methods of Advertisement Used for Dairy Programs by Extension Agents

\begin{tabular}{|c|c|c|c|c|c|c|c|c|c|c|c|c|}
\hline & \multicolumn{2}{|c|}{$\begin{array}{l}\text { Strongly } \\
\text { Disagree }\end{array}$} & \multicolumn{2}{|c|}{$\begin{array}{c}\text { Moderately } \\
\text { Disagree }\end{array}$} & \multicolumn{2}{|c|}{ Disagree } & \multicolumn{2}{|c|}{ Agree } & \multicolumn{2}{|c|}{$\begin{array}{c}\text { Moderately } \\
\text { Agree }\end{array}$} & \multicolumn{2}{|c|}{$\begin{array}{c}\text { Strongly } \\
\text { Agree }\end{array}$} \\
\hline & $n$ & $\%$ & $n$ & $\%$ & $n$ & $\%$ & $n$ & $\%$ & & $\%$ & $n$ & $\%$ \\
\hline Email & 0.0 & 0.0 & 2.0 & 10.5 & 3.0 & 15.8 & 9.0 & 47.4 & 1.0 & 5.3 & 4.0 & 21.1 \\
\hline Mail & 0.0 & 0.0 & 0.0 & 0.0 & 0.0 & 0.0 & 5.0 & 25.0 & 0.0 & 0.0 & 15.0 & 75.0 \\
\hline Pamphlets & 0.0 & 0.0 & 0.0 & 0.0 & 0.0 & 0.0 & 5.0 & 25.0 & 2.0 & 10.0 & 13.0 & 65.0 \\
\hline Flyers & 0.0 & 0.0 & 0.0 & 0.0 & 0.0 & 0.0 & 5.0 & 25.0 & 3.0 & 15.0 & 12.0 & 60.0 \\
\hline Word of Mouth & 0.0 & 0.0 & 0.0 & 0.0 & 1.0 & 5.0 & 8.0 & 40.0 & 5.0 & 25.0 & 6.0 & 30.0 \\
\hline Exhibits & 1.0 & 5.3 & 2.0 & 10.5 & 9.0 & 47.4 & 6.0 & 31.6 & 0.0 & 0.0 & 1.0 & 5.3 \\
\hline Radio & 5.0 & 26.3 & 0.0 & 0.0 & 12.0 & 63.2 & 1.0 & 5.3 & 0.0 & 0.0 & 1.0 & 5.3 \\
\hline Farm visits & 0.0 & 0.0 & 0.0 & 0.0 & 2.0 & 10.0 & 13.0 & 65.0 & 0.0 & 0.0 & 5.0 & 25.0 \\
\hline Television & 7.0 & 36.8 & 0.0 & 0.0 & 12.0 & 63.2 & 0.0 & 0.0 & 0.0 & 0.0 & 0.0 & 0.0 \\
\hline Internet & 1.0 & 5.0 & 0.0 & 0.0 & 5.0 & 25.0 & 9.0 & 45.0 & 2.0 & 10.0 & 3.0 & 15.0 \\
\hline Newspaper & 0.0 & 0.0 & 0.0 & 0.0 & 2.0 & 10.0 & 8.0 & 40.0 & 3.0 & 15.0 & 7.0 & 35.0 \\
\hline Other & 0.0 & 0.0 & 0.0 & 0.0 & 0.0 & 0.0 & 0.0 & 0.0 & 0.0 & 0.0 & 0.0 & 0.0 \\
\hline
\end{tabular}

When asked if they used farm visits as a method of advertisement five of the respondents (25\%) strongly agreed, 13 (65\%) agreed and two (10\%) disagreed. All 19 respondents (100\%) expressed disagreement when asked if they use television as a method of advertisement. Twelve respondents (63.2\%) disagreed and seven (36.8\%) strongly disagreed (see Table 2). 
Most respondents (90\%) were in some sort of agreement when asked if they used the newspaper as a method of advertisement for dairy programs. Seven (35\%) strongly agreed, three (15\%) moderately agreed and eight (40\%) agreed to using the newspaper. Two respondents (10\%) disagreed to using the newspaper as a form of advertisement (see Table 2).

Teaching Methods Used During Dairy Programs by Extension Agents

Extension Agents were asked to indicate what types of teaching methods they used when teaching dairy programs. Seven respondents (35\%) strongly agreed that they used demonstrations as a teaching method while two respondents (10\%) moderately agreed and nine (45\%) agreed to using demonstrations. Two of the respondents (10\%) disagreed to using demonstrations (see Table 3). Fifteen of the respondents (75\%) expressed agreement when asked if they used computer software as a teaching method. Two respondents (10\%) strongly agreed, three (15\%) moderately agreed and 10 (50\%) agreed. Four of the respondents (20\%) disagreed while one of the respondents (5\%) strongly disagreed to using computer software as a teaching method (see Table 3).

When asked if Extension Agents use lectures as a teaching method, six respondents (30\%) strongly agreed while three (15\%) moderately agreed and 11 (55\%) agreed (see Table 3). Eighteen of the respondents (90\%) expressed agreement when asked if they used pamphlets as a teaching method where three (15\%) strongly agreed, three (15\%) moderately agreed and 12 (60\%) agreed. Two respondents (10\%) disagreed to using pamphlets as a teaching method during dairy programs (see Table 3).

Two respondents (10\%) strongly agreed when asked if they used the Internet as a teaching method while two respondents (10\%) moderately agreed and eight respondents 
(40\%) agreed. Eight respondents (40\%) disagreed to using the Internet as a teaching method during dairy programs (see Table 3). When asked if they used videos and/or DVD's as a teaching method, most of the respondents (80\%) were in agreement. Three of the respondents (15\%) strongly agreed, three (15\%) moderately agreed and 10 (50\%) agreed. Four of the respondents (20\%) disagreed to using videos and/or DVD's as a teaching method (see Table 3).

Twelve of the respondents (63.2\%) expressed disagreement when asked if they used audio cassettes and/or CD’s as a teaching method during dairy programs. One respondent (5.3\%) strongly disagreed, one (5.3\%) moderately disagreed and 10 (50\%) disagreed to using audio cassettes and/or CD's. One respondent (5.3\%) moderately agreed and six respondents (31.6\%) agreed to using audio cassettes and/or CD’s as a teaching method during dairy programs (see Table 3). When asked if they used group work as a teaching method, three respondents (15\%) strongly agreed, three (15\%) moderately agreed and twelve of the respondents (60\%) agreed. Two respondents (10\%) disagreed (see Table 3).

Most respondents (90\%) were in agreement when asked if they used fact sheets as a teaching method during dairy programs. Three respondents (15\%) strongly agreed to using this method while six (30\%) moderately agreed and nine (45\%) agreed to using fact sheets as a teaching method. Two respondents (10\%) disagreed to using fact sheets as a teaching method during dairy programs. One respondent (5\%) strongly agreed and seven of the respondents (35\%) agreed when asked if they used books as a teaching method during dairy programs. Ten respondents (50\%) disagreed and two respondents (10\%) strongly disagreed to using books as a teaching method. When asked if other teaching 
methods were used, one respondent moderately agreed and indicated that they used podcasts as a teaching method (see Table 3).

Table 3

Teaching Methods Used During Dairy Programs by Extension Agents

\begin{tabular}{|c|c|c|c|c|c|c|c|c|c|c|c|c|}
\hline & \multicolumn{2}{|c|}{$\begin{array}{l}\text { Strongly } \\
\text { Disagree }\end{array}$} & \multicolumn{2}{|c|}{$\begin{array}{l}\text { Moderately } \\
\text { Disagree }\end{array}$} & \multicolumn{2}{|c|}{ Disagree } & \multicolumn{2}{|c|}{ Agree } & \multicolumn{2}{|c|}{$\begin{array}{c}\text { Moderately } \\
\text { Agree }\end{array}$} & \multicolumn{2}{|c|}{$\begin{array}{l}\text { Strongly } \\
\text { Agree }\end{array}$} \\
\hline & $n$ & $\%$ & $n$ & $\%$ & $n$ & $\%$ & $n$ & $\%$ & $n$ & $\%$ & $n$ & $\%$ \\
\hline Demonstrations & 0.0 & 0.0 & 0.0 & 0.0 & 2.0 & 10.0 & 9.0 & 45.0 & 2.0 & 10.0 & 7.0 & 35.0 \\
\hline Computer Software & 1.0 & 5.0 & 0.0 & 0.0 & 4.0 & 20.0 & 10.0 & 50.0 & 3.0 & 15.0 & 2.0 & 10.0 \\
\hline Lectures & 0.0 & 0.0 & 0.0 & 0.0 & 0.0 & 0.0 & 11.0 & 55.0 & 3.0 & 15.0 & 6.0 & 30.0 \\
\hline Pamphlets & 0.0 & 0.0 & 0.0 & 0.0 & 2.0 & 10.0 & 12.0 & 60.0 & 3.0 & 15.0 & 3.0 & 15.0 \\
\hline Internet & 0.0 & 0.0 & 0.0 & 0.0 & 8.0 & 40.0 & 8.0 & 40.0 & 2.0 & 10.0 & 2.0 & 10.0 \\
\hline $\begin{array}{l}\text { Videos and/or } \\
\text { DVD's }\end{array}$ & 0.0 & 0.0 & 0.0 & 0.0 & 4.0 & 20.0 & 10.0 & 50.0 & 3.0 & 15.0 & 3.0 & 15.0 \\
\hline $\begin{array}{l}\text { Audio Cassettes } \\
\text { and/or CD’s }\end{array}$ & 1.0 & 5.3 & 1.0 & 5.3 & 10 & 52.6 & 6.0 & 31.6 & 1.0 & 5.3 & 0.0 & 0.0 \\
\hline Group Work & 0.0 & 0.0 & 0.0 & 0.0 & 2.0 & 10.0 & 12.0 & 60.0 & 3.0 & 15.0 & 3.0 & 15.0 \\
\hline Fact Sheets & 0.0 & 0.0 & 0.0 & 0.0 & 2.0 & 10.0 & 9.0 & 45.0 & 6.0 & 30.0 & 3.0 & 15.0 \\
\hline Books & 2.0 & 10.0 & 0.0 & 0.0 & 10 & 50.0 & 7.0 & 35.0 & 0.0 & 0.0 & 1.0 & 5.0 \\
\hline Other & 0.0 & 0.0 & 0.0 & 0.0 & 0.0 & 0.0 & 0.0 & 0.0 & 1.0 & 100.0 & 0.0 & 0.0 \\
\hline
\end{tabular}

Dairy Programs Offered by Extension Agents

Extension Agents were asked what types of programs they offered. Fifteen respondents (78.9\%) agreed to offering dairy nutrition programs. One respondent (5.3\%) strongly agreed, four (21.1\%) moderately agreed and 10 of respondents (52.6\%) agreed 
to offering dairy nutrition programs. Three respondents (15.8\%) disagreed and one respondent (5.3\%) strongly disagreed to offering dairy nutrition programs (see Table 4).

Two respondents (10.5\%) strongly agreed when asked if they offered programs related to heifer management while four respondents (21.1\%) moderately agreed and eight (42.1\%) agreed. One respondent (5.3) strongly disagreed and four respondents (21.1\%) disagreed when asked if they offered heifer management programs. Seventeen respondents (89.5\%) in some form agreed when asked if they offered financial management programs (see Table 4). Four respondents (21.1\%) strongly agreed, two respondents (10.5\%) moderately agreed and 11 (57.9\%) agreed. Two respondents (10.5\%) disagreed to offering programs related to financial management (see Table 4). When asked if they offered forage production programs, five respondents (25\%) strongly agreed. Three (15\%) moderately agreed and nine (45\%) agreed to offering forage production programs. One respondent (5\%) strongly disagreed and two respondents (10\%) disagreed to offering forage production programs (see Table 4). One respondent (5.3\%) strongly agreed when asked if programs were offered in milking management while four respondents (21.1\%) moderately agreed and nine (47.4\%) agreed. One respondent (5.3\%) strongly disagreed and four respondents (21.1\%) disagreed to offering milking management programs (see Table 4).

Sixteen respondents (80\%) agreed when asked if they offered herd health programs where one respondent (5\%) strongly agreed, five respondents (20\%) moderately agreed and 10 of the respondents (50\%) agreed. One respondent (5\%) strongly disagreed and three respondents (15\%) disagreed to offering programs related to herd health (see Table 4). Three respondents (15.8\%) strongly agreed when asked if they 
offered programs related to reproduction while two respondents (10.5\%) moderately agreed and 10 (52.6\%) agreed. One respondent (5.3\%) strongly disagreed and three (15.8\%) disagreed to offering reproduction programs (see Table 4).

Four respondents (20\%) strongly agreed when asked if they offered programs related to nutrient management. Two respondents (10\%) moderately agreed and seven respondents (35\%) agreed to offering nutrient management programs. One respondent (5\%) strongly disagreed to offering nutrient management programs while six (30\%) disagreed (see Table 4). Thirteen of the respondents (68.4\%) in some form agreed when asked if they offered programs on barn construction where two respondents (10.5\%) strongly agreed, four (21.1\%) agreed and seven respondents (36.8\%) agreed. One respondent (5.3\%) strongly disagreed and five respondents (26.3\%) disagreed to offering barn construction programs (see Table 4).

Of the respondents, two (10.5\%) strongly agreed when asked if they offered record keeping programs, two (10.5\%) moderately agreed and 10 respondents (52.6\%) agreed. Three respondents (15.8\%) disagreed to offering record keeping programs (see Table 4). Two respondents (10.5\%) moderately agreed and 10 respondents (52.6\%) agreed when asked if they offered dairy quality assurance programs. One respondent (5.3\%) strongly disagreed and six (31.6\%) disagreed that they offer programs related to dairy quality assurance (see Table 4).

Six respondents offered one or more other types of programs. One respondent (16.7\%) offered programs related to pest control and two respondents (33.3\%) offered programs related to risk management. One respondent (16.7\%) offered programs related to labor management and three respondents (50\%) offered programs related to increased 
quality and production. One respondent (16.7\%) offered programs related to mortality and composting and one respondent (16.7\%) offered programs related to farm succession (see Table 4).

Table 4

Dairy Programs Offered by Extension Agents

\begin{tabular}{|c|c|c|c|c|c|c|c|c|c|c|c|c|}
\hline & \multicolumn{2}{|c|}{$\begin{array}{l}\text { Strongly } \\
\text { Disagree }\end{array}$} & \multicolumn{2}{|c|}{$\begin{array}{c}\text { Moderately } \\
\text { Agree }\end{array}$} & \multicolumn{2}{|c|}{ Disagree } & \multicolumn{2}{|c|}{ Agree } & \multicolumn{2}{|c|}{$\begin{array}{c}\text { Moderately } \\
\text { Agree }\end{array}$} & \multicolumn{2}{|c|}{$\begin{array}{l}\text { Strongly } \\
\text { Agree }\end{array}$} \\
\hline & $n$ & $\%$ & $n$ & $\%$ & $n$ & $\%$ & $n$ & $\%$ & $n$ & $\%$ & $n$ & $\%$ \\
\hline Dairy Nutrition & 1.0 & 5.3 & 0.0 & 0.0 & 3.0 & 15.8 & 10.0 & 52.6 & 4.0 & 21.1 & 1.0 & 5.3 \\
\hline $\begin{array}{l}\text { Heifer } \\
\text { Management }\end{array}$ & 1.0 & 5.3 & 0.0 & 0.0 & 4.0 & 21.1 & 8.0 & 42.1 & 4.0 & 21.1 & 2.0 & 10.5 \\
\hline $\begin{array}{l}\text { Financial } \\
\text { Management }\end{array}$ & 0.0 & 0.0 & 0.0 & 0.0 & 2.0 & 10.5 & 11.0 & 57.9 & 2.0 & 10.5 & 4.0 & 21.1 \\
\hline $\begin{array}{l}\text { Forage } \\
\text { Production }\end{array}$ & 1.0 & 5.0 & 0.0 & 0.0 & 2.0 & 10.0 & 9.0 & 45.0 & 3.0 & 15.0 & 5.0 & 25.0 \\
\hline $\begin{array}{l}\text { Milking } \\
\text { Management }\end{array}$ & 1.0 & 5.3 & 0.0 & 0.0 & 4.0 & 21.1 & 9.0 & 47.4 & 4.0 & 21.1 & 1.0 & 5.3 \\
\hline Herd Health & 1.0 & 5.0 & 0.0 & 0.0 & 3.0 & 15.0 & 10.0 & 50.0 & 5.0 & 25.0 & 1.0 & 5.0 \\
\hline Reproduction & 1.0 & 5.3 & 0.0 & 0.0 & 3.0 & 15.8 & 10.0 & 52.6 & 2.0 & 10.5 & 3.0 & 15.8 \\
\hline $\begin{array}{l}\text { Nutrient } \\
\text { Management }\end{array}$ & 1.0 & 5.0 & 0.0 & 0.0 & 6.0 & 30.0 & 7.0 & 35.0 & 2.0 & 10.0 & 4.0 & 20.0 \\
\hline $\begin{array}{l}\text { Barn } \\
\text { Construction }\end{array}$ & 1.0 & 5.3 & 0.0 & 0.0 & 5.0 & 26.3 & 7.0 & 36.8 & 4.0 & 21.1 & 2.0 & 10.5 \\
\hline Record Keeping & 0.0 & 0.0 & 0.0 & 0.0 & 3.0 & 15.8 & 12.0 & 63.2 & 2.0 & 10.5 & 2.0 & 10.5 \\
\hline $\begin{array}{l}\text { Dairy Quality } \\
\text { Assurance }\end{array}$ & 1.0 & 5.3 & 0.0 & 0.0 & 6.0 & 31.6 & 10.0 & 52.6 & 2.0 & 10.5 & 0.0 & 0.0 \\
\hline Other & 0.0 & 0.0 & 0.0 & 0.0 & 0.0 & 0.0 & 0.0 & 0.0 & 2.0 & 33.3 & 4.0 & 66.7 \\
\hline
\end{tabular}




\section{Amish, Hispanic and Disabled Producers in the Extension Agents' Counties}

Extension Agents were asked to indicate how many Amish, Hispanic and/or disabled dairy producers they had in their county. Fourteen of the respondents (58.3\%) had Amish producers in their counties; five respondents (20.8\%) had Hispanic producers within their county, 13 (54.2\%) had disabled producers and six respondents (25\%) had producers of other populations. Of the "other” populations three of the respondents (10\%) reported having Mennonite producers, and three reported having other categories of producers (see Table 5).

Extension Agents were asked if producers of these populations attended their dairy programs. Of the respondents 23 (95.8\%) felt that Amish producers did not attend their programs. Twenty-four respondents (100\%) felt that Hispanic producers did not attend their programs and 24 (100\%) felt that disabled producers did not attend their programs. One respondent (3.3\%) felt that the general public did not attend their programs (see Table 5).

Of the respondents 15 (62.5\%) felt that they made efforts to advertise their programs to the Amish producers, nine (37.5\%) made efforts to advertise their programs to Hispanic producers and 14 (58.3\%) made efforts to advertise their programs to disabled producers. Two respondents (8.3\%) felt they made efforts to advertise to Mennonite producers and one respondent (3.3\%) felt that they made effort to advertise to the general public. Two respondents (6.6\%) felt that they put all reasonable effort forward to advertise for programs (see Table 5). 
Table 5

Amish, Hispanic and Disabled Populations Within the Extension Agents' Counties

\begin{tabular}{llll}
\multicolumn{2}{c}{ No } & \multicolumn{2}{c}{ Yes } \\
\hline$n$ & $\%$ & $n$ & $\%$
\end{tabular}

Producers that reside in Extension Agent's county:

$\begin{array}{lcccc}\text { Amish } & 10.0 & 41.7 & 14.0 & 58.3 \\ \text { Hispanic } & 19.0 & 79.2 & 5.0 & 20.8 \\ \text { Disabled } & 11.0 & 45.8 & 13.0 & 54.2 \\ \text { Other } & 18.0 & 75.0 & 6.0 & 25.0\end{array}$

Producers that do attend dairy programs:

$\begin{array}{lcccc}\text { Amish } & 23.0 & 95.8 & 1.0 & 4.2 \\ \text { Hispanic } & 24.0 & 100.0 & 0.0 & 0.0 \\ \text { Disabled } & 24.0 & 100.0 & 0.0 & 0.0 \\ \text { Other } & 1.0 & 100.0 & 0.0 & 0.0\end{array}$

Efforts are made to advertise programs to the following populations:

$\begin{array}{lcccc}\text { Amish } & 9.0 & 37.5 & 15.0 & 62.5 \\ \text { Hispanic } & 15.0 & 62.5 & 9.0 & 37.5 \\ \text { Disabled } & 10.0 & 41.7 & 14.0 & 58.3 \\ \text { Other } & 18.0 & 75.0 & 6.0 & 25.0\end{array}$

Programs are adjusted to accommodate the following populations:

$\begin{array}{lcccc}\text { Amish } & 10.0 & 41.7 & 14.0 & 58.3 \\ \text { Hispanic } & 19.0 & 79.2 & 5.0 & 20.8 \\ \text { Disabled } & 14.0 & 58.3 & 10.0 & 41.7 \\ \text { Other } & 21.0 & 87.5 & 3.0 & 12.5\end{array}$


Fourteen respondents (58.3\%) felt that they adjusted their programs to accommodate the Amish producers within their county. Five respondents (20.8\%) adjusted programs to accommodate the Hispanic producers in their county while 10 respondents (41.7\%) adjusted programs to accommodate disabled producers. Two respondents (6.6\%) adjusted their programs to accommodate Mennonite producers, while one respondent (3.3) adjust their programs to accommodate all producer populations within their county (see Table 5).

Extension Agents' Opinions of Preferred Information Sources Used by Dairy Producers

Extension Agents were asked to identify the top three sources of information preferred by dairy producers. The responses were reverse coded to obtain a summated score for each information source. The summated score was used to rank the sources of information Extension Agents felt were the most popular for dairy producers. According to Extension Agents the most popular source of information was the veterinarian followed by the farm nutritionist and county Extension Agent, respectively. These sources were followed by neighbor and the farm store employee (see Table 6).

A few respondents checked rather than ranked the sources of information. All rankings were converted to "checks" and the data analyzed. Information sources which were most popular, based on those marked by respondents, were analyzed and compared against the ranked sources, resulting in the same results. The veterinarian was first followed by the farm nutritionist, county Extension Agent, neighbor and farm store employee respectively (see Table 7). When indicating other sources of information, one Extension Agent listed the Artificial Insemination Technician while another listed the Technical Service Technician of the dairy industry (see Appendix E). 
Table 6

Extension Agents' Opinion of Preferred Information Sources Used by Dairy Producers

\begin{tabular}{lcc}
\hline & Sum of Values Rank & Rank \\
\hline Veterinarian & 46.00 & 1 \\
Farm Nutritionist & 38.00 & 2 \\
County Extension & 15.00 & 3 \\
Agent & 8.00 & 4 \\
Neighbor & 3.00 & 5 \\
Farm Store Employee & 3.00 & 6 \\
Other & & \\
\hline
\end{tabular}

Table 7

Extension Agents' Opinions of Preferred Information Sources Used by Dairy Producers

\begin{tabular}{lcc}
\hline & $n$ & $\%$ \\
\hline Veterinarian & 19 & 79.2 \\
Farm Nutritionist & 18 & 75.0 \\
County Extension & 13 & 54.2 \\
Agent & 5 & 20.8 \\
Neighbor & 4 & 16.7 \\
Farm Store Employee & 2 & 8.3 \\
Other & & \\
\hline
\end{tabular}


Programs Offered per Year

Extension Agents were asked how many dairy programs they offered each year.

Two respondents (8.3\%) offered 1-2 programs per year, nine respondents (37.5\%) offered 3-4 programs per year and eight respondents (33.3\%) offered 5 or more programs per year (see Table 8).

Table 8

Number of Programs Offered by Extension Agents per Year

\begin{tabular}{lcc}
\hline & $n$ & $\%$ \\
\hline $1-2$ & 2 & 8.3 \\
$3-4$ & 9 & 37.5 \\
5 or more & 8 & 33.3 \\
\hline
\end{tabular}

Extension Agents' Views on Dairy Producers' Demographics

Extension Agents were asked to provide the average dairy herd size in their county. Three respondents (12.5\%) indicated that the average dairy herd size in their county was 41-60 cows. Eleven respondents (45.8\%) indicated that the average dairy herd size was 61-80 cows, and three respondents (12.5\%) listed the average dairy herd size was 81-100 cows. Three of the respondents (12.5\%) listed that the average dairy herd size in their county was 101 or more cows (see Table 9). 
Table 9

Extension Agents’ Opinions of Average Dairy Herd Size in Their Counties

\begin{tabular}{lcc}
\hline & $n$ & $\%$ \\
\hline $41-60$ & 3 & 12.5 \\
$61-80$ & 11 & 45.8 \\
$81-100$ & 3 & 12.5 \\
101 or more & 3 & 12.5 \\
\hline
\end{tabular}

When asked the average age of dairy producers in their counties, seven (29.2\%)

Extension Agents indicated the average age of producers to be $40-49$ years. Twelve of the respondents (50\%) felt that the average age of producers in their county was 50-59 years and one respondent (4.2\%) felt the average age of producers in their county was 60 years or older (see Table 10).

Table 10

Extension Agents' Opinions of Average Age of Dairy Producers in Their Counties

\begin{tabular}{lcc}
\hline & $n$ & $\%$ \\
\hline $40-49$ years & 7 & 29.2 \\
$50-59$ years & 12 & 50.0 \\
60 years or older & 1 & 4.2 \\
\hline
\end{tabular}

\section{Extension Agents’ Additional Comments}

A section was offered for additional comments at the end of the survey. One respondent stated that Lancaster County is different from the rest of Pennsylvania because of the size of the industry. Therefore he felt his responses would be different 
from the rest. Four Extension Agents stated that they were never or not currently the dairy agent. One respondent only worked with 4-H youth and one respondent worked one-on-one upon request with the few dairies left in his county (see Appendix F).

\section{Dairy Producers}

Dairy Producers’ Attitudes Toward Extension Dairy Programs

Dairy producers were asked to express their attitudes toward their dairy Extension Agent and programs. Ninety-nine respondents (94.3\%) were in agreement when asked if the Extension Agent in their county has dairy programs. Thirty-nine respondents (37.1\%) strongly agreed, 14 respondents (13.3\%) moderately agreed and 46 (43.8\%) agreed to having dairy programs offered by their Extension Agent. Four respondents (3.8\%) disagreed while two (1.9\%) strongly disagreed to having dairy programs offered in their county. One respondent made the comment that he/she was unsure if the Extension Agent offered dairy programs (see Table 11).

Twenty-three respondents (23.0\%) strongly agreed when asked if the Extension Agent was able to answer most dairy questions. Nineteen respondents (19\%) moderately agreed while 43 (43\%) agreed. Three respondents (3\%) strongly disagreed that Extension Agents were able to answer most dairy questions, six (6\%) moderately disagreed and six (6\%) disagreed. Two respondents did not know if the Extension Agent was able to answer dairy questions while one respondent did not ask questions and another indicated they did not ask a lot of questions (see Table 11).

Most respondents (89.7\%) were in some form of agreement when asked if the Extension Agent returned phone calls and emails quickly. Thirty-two (33.0\%) strongly agreed, 13 (13.4\%) moderately agreed and 42 respondents (43.3\%) agreed. One 
respondent (1.0\%) strongly disagreed to the Extension Agent returning calls and emails quickly, two (2.1\%) moderately disagreed and seven respondents (7.2\%) disagreed. One respondent did not know if the Extension Agent returned calls and emails quickly while 3 respondents did not use email (see Table 11).

Respondents were asked if the Extension Agent was a reliable source for dairy information. Twenty-two respondents (23.2\%) strongly agreed, 18 (18.9\%) moderately agreed and 42 respondents (44.2\%) agreed. Three respondents (3.2\%) strongly disagreed that the Extension Agent was a reliable source for dairy information, three respondents (3.2\%) moderately disagreed and seven (7.4\%) disagreed. Two respondents were uncertain if the Extension Agent was a reliable source for dairy information and two respondents report using the Extension Agent little to none (see Table 11).

Fourteen respondents (13.3\%) strongly agreed when asked if they were willing to attend programs on dairy production, 21 respondents (20.0\%) moderately agreed and 57 (54.3\%) agreed. Two respondents (1.9\%) strongly disagreed to be willing to attend programs and 11 (10.5\%) disagreed. One respondent noted that he would attend dairy programs if he/she liked them and one respondent noted that he would not attend (see Table 11).

Twelve respondents (11.7\%) strongly agreed when asked if they would be willing to accept new practices, 30 (20.1\%) moderately agreed and 54 respondents (52.4\%) agreed. Two respondents (1.9\%) strongly disagreed and five respondents (4.9\%) disagreed to being willing to accept new practices. One respondent did not know if he would accept the practices and one respondent noted that it depended on the practices (see Table 11). 
Table 11

Dairy Producers’ Attitudes Toward Extension Dairy Programs

\begin{tabular}{|c|c|c|c|c|c|c|c|c|c|c|c|c|}
\hline & \multicolumn{2}{|c|}{$\begin{array}{l}\text { Strongly } \\
\text { Disagree }\end{array}$} & \multicolumn{2}{|c|}{$\begin{array}{l}\text { Moderately } \\
\text { Disagree }\end{array}$} & \multicolumn{2}{|c|}{ Disagree } & \multicolumn{2}{|c|}{ Agree } & \multicolumn{2}{|c|}{$\begin{array}{c}\text { Moderately } \\
\text { Agree }\end{array}$} & \multicolumn{2}{|c|}{$\begin{array}{l}\text { Strongly } \\
\text { Agree }\end{array}$} \\
\hline & $n$ & $\%$ & $n$ & $\%$ & $n$ & $\%$ & $n$ & $\%$ & $n$ & $\%$ & $n$ & $\%$ \\
\hline $\begin{array}{l}\text { Extension Agent } \\
\text { Offers programs in } \\
\text { dairy production }\end{array}$ & 2.0 & 1.9 & 0.0 & 0.0 & 4.0 & 3.8 & 46.0 & 43.8 & 14.0 & 13.3 & 39.0 & 37.1 \\
\hline $\begin{array}{l}\text { Extension Agent is } \\
\text { able to answer most } \\
\text { questions }\end{array}$ & 3.0 & 3.0 & 6.0 & 6.0 & 6.0 & 6.0 & 43.0 & 43.0 & 19.0 & 19.0 & 23.0 & 23.0 \\
\hline $\begin{array}{l}\text { Extension Agent } \\
\text { returns calls and } \\
\text { emails quickly }\end{array}$ & 1.0 & 1.0 & 2.0 & 2.1 & 7.0 & 7.2 & 42.0 & 43.3 & 13.0 & 13.4 & 32.0 & 33.0 \\
\hline $\begin{array}{l}\text { Extension Agent is } \\
\text { a reliable source for } \\
\text { dairy questions }\end{array}$ & 3.0 & 3.2 & 3.0 & 3.2 & 7.0 & 7.4 & 42.0 & 44.2 & 18.0 & 18.9 & 22.0 & 23.2 \\
\hline $\begin{array}{l}\text { I am willing to } \\
\text { attend programs }\end{array}$ & 2.0 & 1.9 & 0.0 & 0.0 & 11.0 & 10.5 & 57.0 & 54.3 & 21.0 & 20.0 & 14.0 & 13.3 \\
\hline $\begin{array}{l}\text { I am willing to } \\
\text { accept new } \\
\text { practices }\end{array}$ & 2.0 & 1.9 & 0.0 & 0.0 & 5.0 & 4.9 & 54.0 & 52.4 & 30.0 & 29.1 & 12.0 & 11.7 \\
\hline
\end{tabular}

Dairy Producers’ Preferred Methods of Advertisement for Dairy Programs

Dairy producers were asked to indicate preferred methods of advertisement for dairy programs. Thirteen respondents (14\%) strongly disagreed when asked if they preferred email as an advertisement method. Six respondents (6.5\%) moderately disagreed and 31 (33.3\%) disagreed to the use of emails as an advertisement method. Six respondents (6.5\%) strongly agreed to the use of emails, six (6.5\%) moderately agreed 
and 31 (33.3\%) agreed to the use of emails as a preferred method of advertisement. Three respondents noted that they either did not have or did not use email (see Table 12).

Most respondents (96.1\%) were in some sort of agreement when asked if they preferred mail as a method of advertisement. Thirty-eight respondents (37.3\%) strongly agreed, 20 (19.6\%) moderately agreed and 40 of respondents (39.2\%) agreed to preferring mail as an advertisement method. One respondent (1.0\%) strongly disagreed and three respondents (2.9\%) disagreed to preferring mail (see Table 12). Twenty-three respondents (22.5\%) strongly agreed to preferring pamphlets as an advertisement method. Twenty-seven respondents (26.5\%) moderately agreed and 40 (39.2\%) agreed to preferring pamphlets as an advertisement method. One respondent (1\%) strongly disagreed to the use of pamphlets, three (2.9\%) moderately disagreed and eight (7.8\%) disagreed (see Table 12).

Most respondents (86.3\%) were in some form of agreement when asked if they preferred the use of flyers as a form of advertisement for dairy programs. Nineteen respondents (18.4\%) strongly agreed, 30 respondents (29.1\%) moderately agreed and 40 (38.8\%) agreed to preferring flyers as an advertisement method. Two respondents (1.9\%) strongly disagree to preferring flyers, three (2.9\%) moderately disagreed and nine respondents (8.7\%) disagreed (see Table 12). Eleven respondents (10.8\%) strongly agreed when asked if they preferred word of mouth as a form of advertisement for dairy programs. Eleven respondents (10.8\%) moderately agreed and 39 (38.2\%) agreed to preferring word of mouth as an advertisement method for dairy programs. Eight respondents (7.8\%) strongly disagreed, four respondents (3.9\%) moderately disagreed 
and 29 (28.4\%) disagreed to preferring word of mouth as an advertisement method for dairy programs (see Table 12).

When asked if they preferred exhibits as a preferred method of advertisement for dairy programs, seven respondents (7.2\%) strongly agreed. Ten respondents (10.3\%) moderately agreed and 54 respondents (55.7\%) agreed to preferring exhibits as an advertisement method. Three respondents (3.1\%) strongly disagreed, two respondents (2.1\%) moderately disagreed and 21 respondents (21.6\%) disagreed to preferring the use of exhibits as an advertisement method for dairy programs. Three respondents expressed that they did not attend exhibits (see Table 12).

Eight respondents (8.2\%) strongly agreed when asked if they preferred the use of radio as an advertisement method for dairy programs. Thirteen respondents (13.3\%) moderately agreed and 32 (32.7\%) agreed to preferring radio as an advertisement method. Thirteen respondents (13.3\%) strongly disagreed to preferring radio. Four respondents (4.1\%) moderately disagreed and 28 (28.6\%) disagreed to preferring radio as a method of advertisement for dairy programs. Two respondents noted that they did not have a radio (see Table 12).

Dairy producers were asked if they preferred farm visits as a method of advertisement for dairy programs. Fifteen respondents (14.9\%) strongly agreed, 25 (24.8\%) moderately agreed and 46 respondents (45.5\%) agreed to preferring farm visits as a method of advertisement. One respondent (1\%) strongly disagreed, three respondents (3\%) moderately disagreed and 11 (10.9\%) disagreed to preferring farm visits as a method of advertisement for dairy programs (see Table 12). When asked if they preferred the use of television as an advertisement method 18 respondents (18.8\%) strongly 
disagreed, eight respondents (8.3\%) moderately disagreed and 40 (41.7\%) disagreed. Five respondents (5.2\%) strongly agreed, four respondents (4.2\%) moderately agreed and 21 (21.9\%) agreed to preferring television as a form of advertisement for dairy programs. Two respondents expressed that they did not have a television (see Table 12).

Thirteen respondents (13.5\%) strongly disagreed when asked if they preferred the Internet as a form of advertisement. Four respondents (4.2\%) moderately disagreed and 33 respondents (34.4\%) disagreed to preferring the Internet. Five respondents (5.2\%) strongly agreed, four respondents (4.2\%) moderately agreed and 37 respondents (38.5\%) agreed to preferring the use of the Internet as a method of advertisement for dairy programs. Three respondents noted that they did not have Internet (see Table 12). Seventeen respondents (17\%) strongly agreed when asked if they preferred the use of the newspaper as a method of advertisement. Twenty-two (22\%) moderately agreed and 44 (44\%) agreed to preferring the newspaper. Four respondents (4\%) strongly disagreed to preferring the use of the newspaper, three respondents (3\%) moderately disagreed and 10 respondents (10\%) disagreed. One respondent noted that the daily paper was not for farming and one respondent noted that he/she used the Lancaster Farming Newspaper (see Table 12). Four respondents (3.5\%) strongly agreed when asked if they preferred another method of advertisement. Three respondents (2.6\%) noted the use of a farm paper or magazine, notably Lancaster Farming and one respondent (0.9\%) personally called the Extension Agent (See Table 12). 
Table 12

Dairy Producers' Preferred Methods of Advertisement for Dairy Programs

\begin{tabular}{|c|c|c|c|c|c|c|c|c|c|c|c|c|}
\hline & \multicolumn{2}{|c|}{$\begin{array}{l}\text { Strongly } \\
\text { Disagree }\end{array}$} & \multicolumn{2}{|c|}{$\begin{array}{c}\text { Moderately } \\
\text { Disagree }\end{array}$} & \multicolumn{2}{|c|}{ Disagree } & \multicolumn{2}{|c|}{ Agree } & \multicolumn{2}{|c|}{$\begin{array}{l}\text { Moderately } \\
\text { Agree }\end{array}$} & \multicolumn{2}{|c|}{$\begin{array}{l}\text { Strongly } \\
\text { Agree }\end{array}$} \\
\hline & $n$ & $\%$ & $n$ & $\%$ & $n$ & $\%$ & $n$ & $\%$ & $n$ & $\%$ & $n$ & $\%$ \\
\hline Email & 13.0 & 14.0 & 6.0 & 6.5 & 31.0 & 33.3 & 31.0 & 33.3 & 6.0 & 6.5 & 6.0 & 6.5 \\
\hline Mail & 1.0 & 1.0 & 0.0 & 0.0 & 3.0 & 2.9 & 40.0 & 39.2 & 20.0 & 19.6 & 38.0 & 37.3 \\
\hline Pamphlets & 1.0 & 1.0 & 3.0 & 2.9 & 8.0 & 7.8 & 40.0 & 39.2 & 27.0 & 26.5 & 23.0 & 22.5 \\
\hline Flyers & 2.0 & 1.9 & 3.0 & 2.9 & 9.0 & 8.7 & 40.0 & 38.8 & 30.0 & 29.1 & 19.0 & 18.4 \\
\hline Word of Mouth & 8.0 & 7.8 & 4.0 & 3.9 & 29.0 & 28.4 & 39.0 & 38.2 & 11.0 & 10.8 & 11.0 & 10.8 \\
\hline Exhibits & 3.0 & 3.1 & 2.0 & 2.1 & 21.0 & 21.6 & 54.0 & 55.7 & 10.0 & 10.3 & 7.0 & 7.2 \\
\hline Radio & 13.0 & 13.3 & 4.0 & 4.1 & 28.0 & 28.6 & 32.0 & 32.7 & 13.0 & 13.3 & 8.0 & 8.2 \\
\hline Farm Visits & 1.0 & 1.0 & 3.0 & 3.0 & 11.0 & 10.9 & 46.0 & 45.5 & 25.0 & 24.8 & 15.0 & 14.9 \\
\hline Television & 18.0 & 18.8 & 8.0 & 8.3 & 40.0 & 41.7 & 21.0 & 21.9 & 4.0 & 4.2 & 5.0 & 5.2 \\
\hline Internet & 13.0 & 13.5 & 4.0 & 4.2 & 33.0 & 34.4 & 37.0 & 38.5 & 4.0 & 4.2 & 5.0 & 5.2 \\
\hline Newspaper & 4.0 & 4.0 & 3.0 & 3.0 & 10.0 & 10.0 & 44.0 & 44.0 & 22.0 & 22.0 & 17.0 & 17.0 \\
\hline Other & 0.0 & 0.0 & 0.0 & 0.0 & 0.0 & 0.0 & 0.0 & 0.0 & 0.0 & 0.0 & 4.0 & 100.0 \\
\hline
\end{tabular}

Dairy Producers' Preferred Teaching Methods Used During Dairy Programs

Dairy producers were asked their preferred teaching methods to be used during dairy programs. Forty-one respondents (38.3\%) strongly agreed when asked if they preferred demonstrations as a teaching method during dairy programs. Twenty-five respondents (23.4\%) moderately agreed and 38 respondents (35.5\%) agreed to preferring demonstrations. Two respondents (1.9\%) strongly disagreed to preferring demonstrations and one respondent (0.9\%) disagreed (see Table 13). When asked if they preferred the 
use of computer software as a teaching method during programs five respondents (4.8\%) strongly agreed. Twenty-five respondents (23.8\%) moderately agreed and 37 (35.2\%) agreed to preferring the use of computer software as a teaching method. Nine respondents (8.6\%) strongly disagreed, four respondents (3.8\%) moderately disagreed and 25 respondents (23.8\%) disagreed to preferring the use of computer software as a teaching method during dairy programs (see Table 13).

Ninety-one respondents (86.7\%) were in some sort of agreement when asked if they preferred the use of lectures as a teaching method during dairy programs. Nine respondents (8.6\%) strongly agreed, 22 respondents (21\%) moderately agreed and 60 respondents (57.1\%) agreed to preferring lectures. Two respondents (1.9\%) strongly disagreed, four (3.8\%) moderately disagreed and eight respondents (7.6\%) disagreed to preferring the use of lectures as a teaching method during dairy programs (see Table 13). When asked if they preferred the use of pamphlets as a teaching method during dairy programs, five respondents (4.8\%) strongly agreed. Twenty-three respondents $(21.9 \%)$ moderately agreed and 57 (54.3\%) agreed to preferring the use of pamphlets. Three respondents (2.9\%) strongly disagree, three respondents (2.9\%) moderately disagree and 14 respondents (13.3\%) disagree to preferring the use of pamphlets as a teaching method during dairy programs (see Table 13).

Twelve respondents (11.9\%) strongly disagreed when asked if they preferred the Internet as a teaching method for dairy programs while five respondents (5\%) moderately disagreed and 31 (30.7\%) disagreed. Two respondents (2\%) strongly agreed, 10 respondents (9.9\%) moderately agreed and 41 respondents (40.6\%) agreed to prefer the use of Internet as a teaching method for dairy programs (see Table 13). Of the 103 
respondents, $13(12.6 \%)$ strongly agreed when asked if they preferred the use of videos and/or DVD’s as a teaching method during dairy programs. Thirty-two respondents (31.1\%) moderately agreed and 39 respondents (37.9\%) agreed to prefer the use of videos and/or DVD’s. Six respondents (5.8\%) strongly disagreed, two respondents (1.9\%) moderately disagreed and 11 respondents (10.7\%) disagreed to preferring the use of videos and/or DVD’s as a teaching method during dairy programs (see Table 13).

Seven respondents (6.9\%) strongly agreed, nine respondents (8.8\%) moderately agreed and 37 respondents (36.3\%) agreed when asked if they preferred the use of audio cassettes and/or CD’s as a teaching method during dairy programs. Eight respondents (7.8\%) strongly disagreed to preferring the use of audio cassettes and/or CD's while five respondents (4.9\%) moderately disagreed and 36 respondents (35.3\%) disagreed (see Table 13). When asked if they preferred group work as a teaching method most respondents (84.8\%) were in some form of agreement. Sixteen respondents (15.1\%) strongly agreed, 19 respondents (17.9\%) moderately agreed and 54 respondents (50.9\%) agreed to prefer the use of group work. Four respondents (3.8\%) strongly disagreed, one respondent (0.9\%) moderately disagreed and 12 respondents (11.3\%) disagreed to preferring the use of group work as a teaching method during dairy programs (see Table 13).

Fourteen respondents (13.5\%) strongly agreed when asked if they preferred the use of fact sheets as a teaching method during dairy programs. Twenty-five respondents (24\%) moderately agreed and 62 (59.6\%) agreed to preferring the use of fact sheets. Two respondents (1.9\%) strongly disagreed and one respondent (1\%) disagreed to preferring the use of fact sheets as a teaching method during dairy programs (see Table 13). When 
asked if books were preferred to be used as a teaching method during dairy programs, nine respondents (8.7\%) strongly agreed. Nineteen respondents (18.3\%) moderately agreed and 51 (49\%) agreed to preferring the use of books as teaching methods during dairy programs. Two respondents (1.9\%) strongly disagreed, six respondents (5.8\%) moderately disagreed and 17 respondents (16.3\%) disagreed to preferring the use of books as a teaching method during dairy programs (see Table 13).

Table 13

Dairy Producers’ Preferred Teaching Methods Used During Dairy Programs

\begin{tabular}{|c|c|c|c|c|c|c|c|c|c|c|c|c|}
\hline & \multicolumn{2}{|c|}{$\begin{array}{l}\text { Strongly } \\
\text { Disagree }\end{array}$} & \multicolumn{2}{|c|}{$\begin{array}{l}\text { Moderately } \\
\text { Disagree }\end{array}$} & \multicolumn{2}{|c|}{ Disagree } & \multicolumn{2}{|c|}{ Agree } & \multicolumn{2}{|c|}{$\begin{array}{l}\text { Moderately } \\
\text { Agree }\end{array}$} & \multicolumn{2}{|c|}{$\begin{array}{l}\text { Strongly } \\
\text { Agree }\end{array}$} \\
\hline & $n$ & $\%$ & $n$ & $\%$ & $n$ & $\%$ & $n$ & $\%$ & $n$ & $\%$ & $n$ & $\%$ \\
\hline Demonstrations & 2.0 & 1.9 & 0.0 & 0.0 & 1.0 & 0.9 & 38.0 & 35.5 & 25.0 & 23.4 & 41.0 & 38.3 \\
\hline $\begin{array}{l}\text { Computer } \\
\text { Software }\end{array}$ & 9.0 & 8.6 & 4.0 & 3.8 & 25.0 & 23.8 & 37.0 & 35.2 & 25.0 & 23.8 & 5.0 & 4.8 \\
\hline Lectures & 2.0 & 1.9 & 4.0 & 3.8 & 8.0 & 7.6 & 60.0 & 57.1 & 22.0 & 21.0 & 9.0 & 8.6 \\
\hline Pamphlets & 3.0 & 2.9 & 3.0 & 2.9 & 14.0 & 13.3 & 57.0 & 54.3 & 23.0 & 21.9 & 5.0 & 4.8 \\
\hline Internet & 12.0 & 11.9 & 5.0 & 5.0 & 31.0 & 30.7 & 41.0 & 40.6 & 10.0 & 9.9 & 2.0 & 2.0 \\
\hline $\begin{array}{l}\text { Videos and/or } \\
\text { DVD's }\end{array}$ & 6.0 & 5.8 & 2.0 & 1.9 & 11.0 & 10.7 & 39.0 & 37.9 & 32.0 & 31.1 & 13.0 & 12.6 \\
\hline $\begin{array}{l}\text { Audio cassettes } \\
\text { and/or CD's }\end{array}$ & 8.0 & 7.8 & 5.0 & 4.9 & 36.0 & 35.3 & 37.0 & 36.3 & 9.0 & 8.8 & 7.0 & 6.9 \\
\hline Group Work & 4.0 & 3.8 & 1.0 & 0.9 & 12.0 & 11.3 & 54.0 & 50.9 & 19.0 & 17.9 & 16.0 & 15.1 \\
\hline Fact sheets & 2.0 & 1.9 & 0.0 & 0.0 & 1.0 & 1.0 & 62.0 & 59.6 & 25.0 & 24.0 & 14.0 & 13.5 \\
\hline Books & 2.0 & 1.9 & 6.0 & 5.8 & 17.0 & 16.3 & 51.0 & 49.0 & 19.0 & 18.3 & 9.0 & 8.7 \\
\hline Other & 0.0 & 0.0 & 0.0 & 0.0 & 0.0 & 0.0 & 2.0 & 66.7 & 0.0 & 0.0 & 1.0 & 33.3 \\
\hline
\end{tabular}


Three respondents (2.6\%) preferred other teaching methods be used. One respondent $(0.88 \%)$ strongly agreed to preferring the use of hands on activities, one respondent $(0.88 \%)$ agreed to preferring the use of on farm tours and one respondent (0.88\%) agreed to preferring monthly newsletters as a teaching method (see Table 13 ). Programs Preferred by Dairy Producers

Dairy producers were asked what types of dairy Extension programs they preferred. Forty-one respondents (37.6\%) strongly agreed when asked if they preferred programs related to dairy nutrition. Twenty-five respondents (22.9\%) moderately agreed and 41 (37.6\%) agreed that they preferred programs related to dairy nutrition. Two respondents (1.8\%) disagreed that they prefer programs related to dairy nutrition (see Table 14).

When asked if they prefer heifer management programs 40 respondents (36.7\%) strongly agreed, 25 respondents (22.9\%) moderately agreed and 40 respondents (36.7\%) agreed. Four respondents (3.7\%) disagreed that they prefer heifer management programs (see Table 14).

When asked if they preferred financial management programs, 30 respondents (28\%) strongly agreed. Twenty-six respondents (24.3\%) moderately agreed and 45 respondents (42.1\%) agreed that they prefer financial management programs. One respondent (0.9\%) strongly disagreed and five respondents (4.7\%) disagreed that they prefer financial management programs (see Table 14).

Forty-one respondents (37.6\%) strongly agreed when asked if they prefer forage production programs where 32 respondents (29.4\%) moderately agreed and 33 
respondents (30.3\%) agreed. Three respondents (2.8\%) disagreed to preferring forage production programs (see Table 14).

Thirty-one respondents (28.4\%) strongly agreed when asked if they prefer programs related to milking management. Thirty-six respondents (33\%) moderately agreed and 41 respondents (37.6\%) agreed to preferring milking management programs. One respondent (0.9\%) disagreed to preferring milking management programs (see Table 14).

When asked if they preferred herd health programs most respondents (99.1\%) were in some form of agreement. Forty-seven respondents (43.1\%) strongly agreed, 31 respondents (28.4\%) moderately agreed and 30 respondents (27.5\%) agreed to preferring programs related to herd health. One respondent (0.9\%) disagreed to preferring programs on herd health (see Table 14).

Fifty respondents (45.9\%) strongly agreed when asked if they prefer programs related to reproduction. Twenty-eight respondents (25.7\%) moderately agreed and 30 respondents (27.5\%) agreed to preferring reproduction programs. One respondent (0.9\%) disagreed to preferring reproduction programs (see Table 14). Thirty-one respondents (28.7\%) strongly agreed, 21 respondents (19.4\%) moderately agreed and 52 respondents (48.1\%) agreed when asked if they preferred programs related to nutrient management. Four respondents (3.7\%) disagreed to preferring nutrient management programs (see Table 14).

When asked if they prefer barn construction programs, 19 respondents (17.6\%) strongly agreed to preferring this type of program. Twenty respondents (18.5\%) moderately agreed and 55 respondents (50.9\%) agreed to preferring barn construction 
programs. Four respondents (3.7\%) strongly disagreed, one respondent (0.9\%) moderately disagreed and nine respondents (8.3\%) disagreed to preferring barn construction programs (see Table 14).

Twenty respondents (18.5\%) strongly agreed when asked if they prefer record keeping programs. Twenty-six respondents (24.1\%) moderately agreed and 49 respondents (45.4\%) agreed to preferring record keeping programs. One respondent (0.9\%) strongly disagreed, one respondent ( $0.9 \%)$ moderately disagreed and eleven respondents (10.2\%) disagreed to preferring programs related to record keeping (see Table 14).

When asked if they prefer dairy quality assurance programs most respondents (93.6\%) were in some form of agreement. Twenty-four respondents (22.2\%) strongly agreed, 21 respondents (19.4\%) moderately agreed and 56 respondents (51.9\%) agreed to preferring programs related to dairy quality assurance. One respondent $(0.9 \%)$ strongly disagreed, one respondent (0.9\%) moderately disagreed and five respondents (4.6\%) disagreed to preferring dairy quality assurance programs (see Table 14).

Eight respondents (7\%) preferred that other programs be offered by the Extension Agent. Two respondents preferred programs related to animal care, one respondent preferred programs related to employee management and one respondent preferred programs related to passing the farm to the next generation. One respondent preferred programs that teach new practices, one respondent preferred programs related to organic and conventional milk and one respondent preferred programs to help receive a pesticide license (see Table 14). 
Table 14

Dairy Producers’ Preferred Program Topics

\begin{tabular}{|c|c|c|c|c|c|c|c|c|c|c|c|c|}
\hline & \multicolumn{2}{|c|}{$\begin{array}{l}\text { Strongly } \\
\text { Disagree }\end{array}$} & \multicolumn{2}{|c|}{$\begin{array}{l}\text { Moderately } \\
\text { Disagree }\end{array}$} & \multicolumn{2}{|c|}{ Disagree } & \multicolumn{2}{|c|}{ Agree } & \multicolumn{2}{|c|}{$\begin{array}{c}\text { Moderately } \\
\text { Agree }\end{array}$} & \multicolumn{2}{|c|}{$\begin{array}{l}\text { Strongly } \\
\text { Agree }\end{array}$} \\
\hline & $n$ & $\%$ & $n$ & $\%$ & $n$ & $\%$ & $n$ & $\%$ & $n$ & $\%$ & $n$ & $\%$ \\
\hline $\begin{array}{l}\text { Dairy } \\
\text { Nutrition }\end{array}$ & 0.0 & 0.0 & 0.0 & 0.0 & 2.0 & 1.8 & 41.0 & 37.6 & 25.0 & 22.9 & 41.0 & 37.6 \\
\hline $\begin{array}{l}\text { Heifer } \\
\text { Management }\end{array}$ & 0.0 & 0.0 & 0.0 & 0.0 & 4.0 & 3.7 & 40.0 & 36.7 & 25.0 & 22.9 & 40.0 & 36.7 \\
\hline $\begin{array}{l}\text { Financial } \\
\text { Management }\end{array}$ & 1.0 & 0.9 & 0.0 & 0.0 & 5.0 & 4.7 & 45.0 & 42.1 & 26.0 & 24.3 & 30.0 & 28.0 \\
\hline $\begin{array}{l}\text { Forage } \\
\text { Production }\end{array}$ & 0.0 & 0.0 & 0.0 & 0.0 & 3.0 & 2.8 & 33.0 & 30.3 & 32.0 & 29.4 & 41.0 & 37.6 \\
\hline $\begin{array}{l}\text { Milking } \\
\text { Management }\end{array}$ & 0.0 & 0.0 & 0.0 & 0.0 & 1.0 & 0.9 & 41.0 & 37.6 & 36.0 & 33.0 & 31.0 & 28.4 \\
\hline Herd Health & 0.0 & 0.0 & 0.0 & 0.0 & 1.0 & 0.9 & 30.0 & 27.5 & 31.0 & 28.4 & 47.0 & 43.1 \\
\hline Reproduction & 0.0 & 0.0 & 0.0 & 0.0 & 1.0 & 0.9 & 30.0 & 27.5 & 28.0 & 25.7 & 50.0 & 45.9 \\
\hline $\begin{array}{l}\text { Nutrient } \\
\text { Management }\end{array}$ & 0.0 & 0.0 & 0.0 & 0.0 & 4.0 & 3.7 & 52.0 & 48.1 & 21.0 & 19.4 & 31.0 & 28.7 \\
\hline $\begin{array}{l}\text { Barn } \\
\text { Construction }\end{array}$ & 4.0 & 3.7 & 1.0 & 0.9 & 9.0 & 8.3 & 55.0 & 50.9 & 20.0 & 18.5 & 19.0 & 17.6 \\
\hline $\begin{array}{l}\text { Record } \\
\text { Keeping }\end{array}$ & 1.0 & 0.9 & 1.0 & 0.9 & 11.0 & 10.2 & 49.0 & 45.4 & 26.0 & 24.1 & 20.0 & 18.5 \\
\hline $\begin{array}{l}\text { Dairy Quality } \\
\text { Assurance }\end{array}$ & 1.0 & 0.9 & 1.0 & 0.9 & 5.0 & 4.6 & 56.0 & 51.9 & 21.0 & 19.4 & 24.0 & 22.2 \\
\hline Other & 0.0 & 0.0 & 0.0 & 0.0 & 0.0 & 0.0 & 0.0 & 0.0 & 1.0 & 12.5 & 7.0 & 87.5 \\
\hline
\end{tabular}




\section{Dairy Producers' Preferred Sources of Dairy Production Information}

Dairy producers were asked to identify the top three sources they use for information. The responses were reverse coded to obtain a summated score for each information source. The summated score was used to rank the sources of information dairy producers used most often. According to dairy producers the most popular source of information was the farm nutritionist followed by the veterinarian and the county Extension Agent, respectively. These sources were followed by neighbors, other sources and the farm store employee (See Table 15).

Table 15

Dairy Producers' Preferred Source of Dairy Production Information

\begin{tabular}{lcc}
\hline & Sum of Values Rank & Rank \\
\hline Farm Nutritionist & 265.00 & 1 \\
Veterinarian & 207.00 & 2 \\
County Extension & 60.00 & 3 \\
Agent & 35.00 & 4 \\
Neighbor & 18.00 & 5 \\
Other & 9.00 & 6 \\
Farm Store Employee & & \\
\hline
\end{tabular}

A few respondents checked rather than ranked the sources of information. All rankings were converted to “checks” and the data analyzed. Information sources which were most popular, based on those marked by respondents, were analyzed and compared against the ranked sources, resulting in the same results. The farm nutritionist was first followed by the farm veterinarian, county Extension Agent, neighbor, other sources and 
the farm store employee respectively (See Table 16). Other sources listed included family, employees, publications; the Internet, etc. (see Appendix H).

Table 16

Dairy Producers' Preferred Source of Dairy Production Information

\begin{tabular}{lcc}
\hline & $n$ & $\%$ \\
\hline Farm Nutritionist & 99 & 90.0 \\
Veterinarian & 96 & 87.3 \\
County Extension & 50 & 45.5 \\
Agent & 29 & 26.4 \\
Neighbor & 10 & 9.0 \\
Other & 9 & 8.2 \\
Farm Store Employee & &
\end{tabular}

Number of Programs Attended by Dairy Producers Each Year

Dairy producers were asked to indicate the number of dairy Extension programs they attend per year. Thirty-three respondents (31.1\%) did not attend any programs, 63 respondents (59.4\%) attended one-two programs, nine respondents (8.5\%) attended threefour programs and one respondent (0.9\%) attended five or more programs (see Table 17). Table 17

Number of Programs Attended by Dairy Producers per Year

\begin{tabular}{lcc}
\hline & $n$ & $\%$ \\
\hline 0 & 33 & 31.1 \\
$1-2$ & 63 & 59.4 \\
$3-4$ & 9 & 8.5 \\
5 or more & 1 & .9 \\
\hline
\end{tabular}


Dairy Producer Demographic Information

Dairy producers were asked to provide the size of their dairy herd. One respondent (0.9\%) had one-20 cattle, one respondent (0.9\%) had 21-40 cattle and 10 respondents (9.3\%) had 41-60 cattle. Sixteen respondents (15\%) had 61-80 cattle, 22 respondents (20.6\%) had 81-100 cattle and 57 respondents (53.3\%) had 101 cattle or more (see Table 18).

Table 18

Dairy Cattle Herd Size of Dairy Producers

\begin{tabular}{lcc}
\hline Head & $n$ & $\%$ \\
\hline $1-20$ & 1 & .9 \\
$21-40$ & 1 & .9 \\
$41-60$ & 10 & 9.3 \\
$61-80$ & 16 & 15.0 \\
$81-100$ & 22 & 20.6 \\
101 or more & 57 & 53.3 \\
\hline
\end{tabular}

Dairy producers were asked to provide their age range. Eleven respondents (10.4\%) were 20-29 years of age, 20 respondents (18.9\%) were 30-39 years of age and 29 respondents (27.4\%) were 40-49 years of age. Thirty-four respondents (32.1\%) were 5059 years of age and 12 respondents (11.3\%) were 60 years or older. Two respondents (1.9\%) noted that their farm was a partnership with the second partner being in the 20-29 age range (see Table 19). 
Table 19

Ages of Dairy Producers

\begin{tabular}{llc}
\hline & $n$ & $\%$ \\
\hline $20-29$ years & 11 & 10.4 \\
$30-39$ years & 20 & 18.9 \\
$40-49$ years & 29 & 27.4 \\
$50-59$ years & 34 & 32.1 \\
60 years or older & 12 & 11.3 \\
\hline
\end{tabular}

Dairy Producers' Additional Comments

Seven respondents (6.1\%) were either unaware of or did not have a dairy Extension Agent in the County. Seven respondents (6.1\%) expressed that they do not use services provided by the Extension office with one noting that the Extension Agent in his/her county only jumps on the bandwagon and does what the Land Grant University wants him to, not what they want him to do. Another stated that they do not attend because Extension meetings cost too much and that they would attend if they cost less. One respondent (0.9\%) felt that dairy Extension Agents repeat information each year and one respondent $(0.9 \%)$ noted that they enjoyed farm meetings and work learning sessions. Two additional respondents (1.8\%) were no longer in the dairy business and two (1.8\%) did not wish to be bothered (see Appendix I).

Comparison of Extension Agents and Dairy Producers in Pennsylvania

The researcher attempted to do a Pearson Chi-Square analysis to compare Extension Agents and dairy producers in Pennsylvania. The number of cells with less than five prevented this type of analysis. Therefore, the researcher evaluated the 
descriptive data to determine if differences occurred between Extension Agents and dairy producers. The next segments address areas where there was an apparent difference between the opinions of Extension Agents and dairy producers. Comparison of Attitudes Toward Attendance at Extension Programs

Extension Agents were asked if they felt dairy producers attended their programs and producers were asked if they attended programs. Most dairy producers (87.6\%) were in agreement that they attended programs while only about three quarters of Extension Agents (76.2\%) agreed that dairy producers attended their programs. None of the Extension Agents (0\%) strongly agreed that producers attend their programs while fourteen dairy producers (13.3\%) strongly agreed that they attended programs. Four Extension Agents (19\%) moderately agreed that producers attend their programs and 21 dairy producers (20\%) moderately agreed that they attend programs. Only six agents (28.6\%) agreed while 57 producers (54.3\%) agreed that programs were attended. One Extension Agent (4.8\%) strongly disagreed that producers attend programs while two producers (1.9\%) strongly disagreed to attending programs. One Extension agent (4.8\%) moderately disagreed to producers attending programs, nine Extension Agents (42.9\%) disagreed to producers attending programs and 11 producers (10.5\%) disagreed to attending programs (see Table 20). 
Table 20

Comparison of Agents and Producers Toward Attendance at Extension Programs

\begin{tabular}{lccccccccccccc}
\hline & $\begin{array}{c}\text { Strongly } \\
\text { Disagree }\end{array}$ & $\begin{array}{c}\text { Moderately } \\
\text { Disagree }\end{array}$ & Disagree & & Agree & $\begin{array}{c}\text { Moderately } \\
\text { Agree }\end{array}$ & \multicolumn{2}{c}{$\begin{array}{c}\text { Strongly } \\
\text { Agree }\end{array}$} \\
\cline { 2 - 13 } & $n$ & $\%$ & $n$ & $\%$ & $n$ & $\%$ & $n$ & $\%$ & $n$ & $\%$ & $n$ & $\%$ \\
\hline Agent & 1.0 & 4.8 & 1.0 & 4.8 & 9.0 & 42.9 & 6.0 & 28.6 & 4.0 & 19.0 & 0.0 & 0.0 \\
Producer & 2.0 & 1.9 & 0.0 & 0.0 & 11.0 & 10.5 & 57.0 & 54.3 & 21.0 & 20.0 & 14.0 & 13.3 \\
\hline
\end{tabular}

\section{Comparison of Attitudes Toward the Use of Mail as an Advertisement Method}

Extension Agents were asked if they use mail as a means of advertisement while dairy producers were asked if they preferred the use of mail as a method of advertisement. All Extension Agents (100\%) were in agreement that they used mail as an advertisement method while almost all producers (96.1\%) were in agreement that they preferred mail as an advertisement method. Fifteen Extension Agents (75\%) strongly agreed to the use of mail as an advertisement method while only 38 dairy producers (37.3\%) strongly agreed to preferring mail as a method of advertisement. None of the Extension Agents (0\%) moderately agreed to using mail while 20 producers (19.6\%) moderately agreed to prefer the use of mail. Five agents (25\%) agreed to prefer the use of mail while 40 producers (39.2\%) agreed to prefer the use of mail as an advertisement method. No agents ( $0 \%$ ) strongly disagreed to using mail and one producer (1\%) strongly disagreed to preferring the use of mail. None of the Extension Agents (0\%) disagreed to using mail while three producers (2.9\%) disagreed to preferring the use of mail as an advertisement method (see Table 21). 
Table 21

Comparison of Agents and Producers Toward Use of Mail to Advertise for Programs

\begin{tabular}{lccccccccccccc}
\hline & \multicolumn{1}{c}{$\begin{array}{c}\text { Strongly } \\
\text { Disagree }\end{array}$} & \multicolumn{2}{c}{$\begin{array}{c}\text { Moderately } \\
\text { Disagree }\end{array}$} & Disagree & Agree & \multicolumn{2}{c}{$\begin{array}{c}\text { Moderately } \\
\text { Agree }\end{array}$} & $\begin{array}{c}\text { Strongly } \\
\text { Agree }\end{array}$ \\
\cline { 2 - 13 } & $n$ & $\%$ & $n$ & $\%$ & $n$ & $\%$ & $n$ & $\%$ & $n$ & $\%$ & $n$ & $\%$ \\
\hline Agent & 0.0 & 0.0 & 0.0 & 0.0 & 0.0 & 0.0 & 5.0 & 25.0 & 0.0 & 0.0 & 15.0 & 75.0 \\
Producer & 1.0 & 1.0 & 0.0 & 0.0 & 3.0 & 2.9 & 40.0 & 39.2 & 20.0 & 19.6 & 38.0 & 37.3 \\
\hline
\end{tabular}

Comparison of Attitudes Toward the Use of Pamphlets as an Advertisement Method

Extension Agents and dairy producers were asked their attitudes toward the use of pamphlets as a method of advertisement. All Extension Agents (100\%) were in some sort of agreement when it came to using pamphlets for advertisement and most producers (88.2\%) were in agreement that they preferred the use of pamphlets. Thirteen Extension Agents (65\%) and 23 producers (22.5\%) strongly agreed to the use of pamphlets as an advertisement method. Two Extension Agents (10\%) and 27 producers (26.5\%) moderately agreed to the use of pamphlets as a method of advertisement. Five Extension Agents (25\%) and 40 dairy producers (39.2\%) agreed to the use of pamphlets for advertisement. None of the Extension Agents (0\%) strongly disagreed to the use of pamphlets while one producer (1\%) strongly disagreed to the use of pamphlets as a method of advertisement. Three producers (2.9\%) moderately disagreed and eight producers (7.8\%) disagreed to the use of pamphlets as an advertisement method (see Table 22). 
Table 22

Comparison of Agents and Producers Toward the Use of Pamphlets to Advertise for Programs

\begin{tabular}{lccccccccccccc}
\hline & $\begin{array}{c}\text { Strongly } \\
\text { Disagree }\end{array}$ & \multicolumn{2}{c}{$\begin{array}{c}\text { Moderately } \\
\text { Disagree }\end{array}$} & Disagree & Agree & \multicolumn{2}{c}{$\begin{array}{c}\text { Moderately } \\
\text { Agree }\end{array}$} & $\begin{array}{c}\text { Strongly } \\
\text { Agree }\end{array}$ \\
\cline { 2 - 13 } & $n$ & $\%$ & $n$ & $\%$ & $n$ & $\%$ & $n$ & $\%$ & $n$ & $\%$ & $n$ & $\%$ \\
\hline Agent & 0.0 & 0.0 & 0.0 & 0.0 & 0.0 & 0.0 & 5.0 & 25.0 & 2.0 & 10.0 & 13.0 & 65.0 \\
Producer & 1.0 & 1.0 & 3.0 & 2.9 & 8.0 & 7.8 & 40.0 & 39.2 & 27.0 & 26.5 & 23.0 & 22.5 \\
\hline
\end{tabular}

Comparison of Attitudes Toward the Use of Flyers as an Advertisement Method

All Extension Agents (100\%) were in agreement when it came to preferring the use of flyers to advertise programs while some dairy producers (13.5\%) disagreed to the preference flyers. Twelve Extension Agents (60\%) strongly agreed to the use of flyers as an advertisement method while only 19 producers (18.4\%) strongly agreed. Three Extension Agents (15\%) moderately agreed while 30 producers (29.1\%) moderately agreed to the use of flyers for advertisement. Five Extension Agents (25\%) agreed to the use of flyers as an advertisement method while 40 producers (38.8\%) agreed. Two producers (1.9\%) strongly disagreed, three producers (2.9\%) moderately disagreed and nine producers $(8.7 \%)$ disagreed to the use of flyers for advertisement for programs (see Table 23). 
Table 23

Comparison of Agents and Producers on Toward Using Flyers to Advertise for Programs

\begin{tabular}{lccccccccccccc}
\hline & $\begin{array}{c}\text { Strongly } \\
\text { Disagree }\end{array}$ & \multicolumn{2}{c}{$\begin{array}{c}\text { Moderately } \\
\text { Disagree }\end{array}$} & Disagree & Agree & \multicolumn{2}{c}{$\begin{array}{c}\text { Moderately } \\
\text { Agree }\end{array}$} & $\begin{array}{c}\text { Strongly } \\
\text { Agree }\end{array}$ \\
\cline { 2 - 12 } & $n$ & $\%$ & $n$ & $\%$ & $n$ & $\%$ & $n$ & $\%$ & $n$ & $\%$ & $n$ & $\%$ \\
\hline Agent & 0.0 & 0.0 & 0.0 & 0.0 & 0.0 & 0.0 & 5.0 & 25.0 & 3.0 & 15.0 & 12.0 & 60.0 \\
Producer & 2.0 & 1.9 & 3.0 & 2.9 & 9.0 & 8.7 & 40.0 & 38.8 & 30.0 & 29.1 & 19.0 & 18.4 \\
\hline
\end{tabular}

Comparison of Attitudes Toward the Use of Word of Mouth as an Advertisement Method

Agents and producers were asked to express their attitudes toward advertising for programs by word of mouth. Nearly all Extension Agents (95\%) expressed disagreement about the use of word of mouth as an advertising method while slightly more than half of the producers (59.8\%) preferred the use of this method. Six Extension Agents (30\%) strongly agreed to using word of mouth as an advertisement while 11 producers $(10.8 \%)$ strongly agreed to preferring word of mouth as an advertisement method. Five agents (25\%) moderately agreed to the use of word of mouth while only 11 producers $(10.8 \%)$ moderately agreed to prefer the use of word of mouth. Eight Extension Agents (40\%) and 39 producers (38.2\%) agreed to advertising using word of mouth. Eight producers (7.8\%) strongly disagreed and four producers (3.9\%) moderately disagreed to preferring the use of word of mouth as an advertisement method. One Extension Agent (5\%) and 29 producers (28.4\%) disagreed to the use of word of mouth to advertise for Extension dairy programs (see Table 24). 
Table 24

Comparison of Agents and Producers Toward the Use of Word of Mouth to Advertise for Programs

\begin{tabular}{lccccccccccccc}
\hline & $\begin{array}{c}\text { Strongly } \\
\text { Disagree }\end{array}$ & \multicolumn{2}{c}{$\begin{array}{c}\text { Moderately } \\
\text { Disagree }\end{array}$} & Disagree & Agree & \multicolumn{2}{c}{$\begin{array}{c}\text { Moderately } \\
\text { Agree }\end{array}$} & $\begin{array}{c}\text { Strongly } \\
\text { Agree }\end{array}$ \\
\cline { 2 - 13 } & $n$ & $\%$ & $n$ & $\%$ & $n$ & $\%$ & $n$ & $\%$ & $n$ & $\%$ & $n$ & $\%$ \\
\hline Agent & 0.0 & 0.0 & 0.0 & 0.0 & 1.0 & 5.0 & 8.0 & 40.0 & 5.0 & 25.0 & 6.0 & 30.0 \\
Producer & 8.0 & 7.8 & 4.0 & 3.9 & 29.0 & 28.4 & 39.0 & 38.2 & 11.0 & 10.8 & 11.0 & 10.8 \\
\hline
\end{tabular}

Comparison of Attitudes Toward the Use of Exhibits as an Advertisement Method

Only about one third of Extension Agents (36.9\%) were in agreement when it came to using exhibits to advertise while almost three fourths of producers (73.2\%) were in disagreement when it came to using exhibits to advertise programs. One Extension Agent (5.3\%) strongly agreed and seven dairy producers (7.2\%) strongly agreed to the use of exhibits as a method of advertisement for dairy programs. Ten producers (10.3\%) moderately agreed to the use of exhibits. Six Extension Agents (31.6\%) agreed to the use of exhibits while 54 producers (55.7\%) agreed. One Extension Agent (5.3\%) and three producers (3.1\%) strongly disagreed to the use of exhibits for an advertisement method for dairy programs. Two Extension Agents (10.5\%) and two producers (2.1\%) moderately disagreed to the use of exhibits while nine agents (47.4\%) disagreed and 21 producers (21.6\%) disagreed to the use of exhibits as advertisement methods for dairy Extension programs (see Table 25). 
Table 25

Comparison of Agents and Producers Toward on Using Exhibits to Advertise for Programs

\begin{tabular}{lccccccccccccc}
\hline & $\begin{array}{c}\text { Strongly } \\
\text { Disagree }\end{array}$ & \multicolumn{2}{c}{$\begin{array}{c}\text { Moderately } \\
\text { Disagree }\end{array}$} & Disagree & Agree & \multicolumn{2}{c}{$\begin{array}{c}\text { Moderately } \\
\text { Agree }\end{array}$} & $\begin{array}{c}\text { Strongly } \\
\text { Agree }\end{array}$ \\
\cline { 2 - 13 } & $n$ & $\%$ & $N$ & $\%$ & $n$ & $\%$ & $n$ & $\%$ & $n$ & $\%$ & $n$ & $\%$ \\
\hline Agent & 1.0 & 5.3 & 2.0 & 10.5 & 9.0 & 47.4 & 6.0 & 31.6 & 0.0 & 0.0 & 1.0 & 5.3 \\
Producer & 3.0 & 3.1 & 2.0 & 2.1 & 21.0 & 21.6 & 54.0 & 55.7 & 10.0 & 10.3 & 7.0 & 7.2 \\
\hline
\end{tabular}

Comparison of Attitudes Toward the Use of Radio as an Advertisement Method

Slightly more than half of the dairy producers (54.2\%) were in agreement when it came to using radio as an advertisement method while only two Extension Agents (10.6\%) were in agreement to the use of radio. One agent (5.3\%) strongly agreed to the use of radio as an advertisement and eight producers (8.2\%) strongly agreed. Thirteen producers (13.3\%) moderately agreed to preferring radio as an advertisement method. One Extension Agent (5.3\%) agreed and 32 producers (32.7\%) agreed to the use of radio to advertise for dairy programs. Five agents (26.3\%) strongly disagreed and 13 producers (13.3\%) strongly disagreed to the use of radio. Four producers (4.1\%) moderately disagreed to the use of radio while 12 Extension Agents (63.2\%) disagreed and 28 producers (28.6\%) disagreed to the use of radio as a method of advertisement for dairy programs (see Table 26). 
Table 26

Comparison of Agents and Producers Toward Using Radio to Advertise for Programs

\begin{tabular}{lccccccccccccc}
\hline & $\begin{array}{c}\text { Strongly } \\
\text { Disagree }\end{array}$ & \multicolumn{2}{c}{$\begin{array}{c}\text { Moderately } \\
\text { Disagree }\end{array}$} & Disagree & Agree & \multicolumn{2}{c}{$\begin{array}{c}\text { Moderately } \\
\text { Agree }\end{array}$} & $\begin{array}{c}\text { Strongly } \\
\text { Agree }\end{array}$ \\
\cline { 2 - 14 } & $n$ & $\%$ & $n$ & $\%$ & $n$ & $\%$ & $n$ & $\%$ & $n$ & $\%$ & $n$ & $\%$ \\
\hline Agent & 5.0 & 26.3 & 0.0 & 0.0 & 12.0 & 63.2 & 1.0 & 5.3 & 0.0 & 0.0 & 1.0 & 5.3 \\
Producer & 13.0 & 13.3 & 4.0 & 4.1 & 28.0 & 28.6 & 32.0 & 32.7 & 13.0 & 13.3 & 8.0 & 8.2 \\
\hline
\end{tabular}

Comparison of Attitudes Toward the Use of Television as an Advertisement Method

Thirty producers (31.3\%) were in agreement when it came to preferring the use of television as an advertisement method for dairy programs while none of the Extension Agents (0\%) were in agreement. Seven Extension Agents (36.8\%) strongly disagreed to the use of television while only 18 producers (18.8\%) strongly disagreed. Eight producers (8.3\%) moderately disagreed to preferring the use of television for advertisement. Twelve agents (63.2\%) disagreed and 40 producers (41.7\%) disagreed to the use of television as a method of advertisement for dairy programs (see Table 27).

Table 27

Comparison of Agents and Producers Toward Using Television to Advertise for Programs

\begin{tabular}{lcccccccccccc}
\hline & $\begin{array}{c}\text { Strongly } \\
\text { Disagree }\end{array}$ & \multicolumn{2}{c}{$\begin{array}{c}\text { Moderately } \\
\text { Disagree }\end{array}$} & Disagree & Agree & \multicolumn{2}{c}{$\begin{array}{c}\text { Moderately } \\
\text { Agree }\end{array}$} & $\begin{array}{c}\text { Strongly } \\
\text { Agree }\end{array}$ \\
\cline { 2 - 12 } & $n$ & $\%$ & $n$ & $\%$ & $n$ & $\%$ & $n$ & $\%$ & $n$ & $\%$ & $n$ & $\%$ \\
\hline Agent & 7.0 & 36.8 & 0.0 & 0.0 & 12.0 & 63.2 & 0.0 & 0.0 & 0.0 & 0.0 & 0.0 & 0.0 \\
Producer & 18.0 & 18.8 & 8.0 & 8.3 & 40.0 & 41.7 & 21.0 & 21.9 & 4.0 & 4.2 & 5.0 & 5.2 \\
\hline
\end{tabular}


Comparison of Attitudes Toward the Use of Books as a Teaching Method

Extension Agents and dairy producers were asked to express their attitudes toward the use of books as a teaching method during dairy Extension programs. Three fourths of the dairy producers (76\%) preferred the use of books as a teaching method while less than half of the Extension Agents (40\%) agreed to the use of books as a teaching method. One Extension Agent (5\%) and nine producers (8.7\%) strongly agreed to the use of books as a teaching method during dairy programs. Nineteen producers (18.3\%) moderately agreed and 51 producers (49\%) agreed to preferring the use of books as an advertisement method. Two agents (10\%) and two producers (1.9\%) strongly disagreed to the use of books as a teaching method during dairy programs while six producers (5.8\%) moderately disagreed. Ten Extension Agents (50\%) disagreed and 17 producers (16.3\%) disagreed to the use of books as a teaching method during dairy programs (see Table 28).

Table 28

Comparison of Agents and Producers Toward the Use of Books as a Teaching Method

\begin{tabular}{lccccccccccccc}
\hline & $\begin{array}{c}\text { Strongly } \\
\text { Disagree }\end{array}$ & $\begin{array}{c}\text { Moderately } \\
\text { Disagree }\end{array}$ & Disagree & Agree & $\begin{array}{c}\text { Moderately } \\
\text { Agree }\end{array}$ & $\begin{array}{c}\text { Strongly } \\
\text { Agree }\end{array}$ \\
\cline { 2 - 14 } & $n$ & $\%$ & $n$ & $\%$ & $n$ & $\%$ & $n$ & $\%$ & $n$ & $\%$ & $n$ & $\%$ \\
\hline Agent & 2.0 & 10.0 & 0.0 & 0.0 & 10.0 & 50.0 & 7.0 & 35.0 & 0.0 & 0.0 & 1.0 & 5.0 \\
Producer & 2.0 & 1.9 & 6.0 & 5.8 & 17.0 & 16.3 & 51.0 & 49.0 & 19.0 & 18.3 & 9.0 & 8.7 \\
\hline
\end{tabular}

Comparison of the Offering of and the Desire for Dairy Nutrition Programs

Nearly all producers (98.1\%) agreed that they desired programs related to dairy nutrition while only around three quarters of the Extension Agents (79\%) agreed to 
offering dairy nutrition programs. One Extension Agent (5.3\%) strongly agreed to offering dairy nutrition programs while 41 producers (37.6\%) strongly agreed that they desired dairy nutrition programs. Four agents (21.1\%) moderately agreed to offering dairy nutrition programs and 25 producers (22.9\%) moderately agreed that they desired dairy nutrition programs. Ten agents (52.6\%) agreed to offering dairy nutrition programs and 41 producers (37.6\%) agreed to wanting programs in dairy nutrition. One agent (5.3\%) strongly disagreed to offering dairy nutrition programs while three agents $(15.8 \%)$ disagreed to offering dairy nutrition programs and two producers $(1.8 \%)$ disagreed to desiring dairy nutrition programs (see Table 29).

Table 29

Comparison of Agents and Producers on the Topic of Dairy Nutrition Programs

\begin{tabular}{lccccccccccccc}
\hline & \multicolumn{1}{c}{$\begin{array}{c}\text { Strongly } \\
\text { Disagree }\end{array}$} & \multicolumn{2}{c}{$\begin{array}{c}\text { Moderately } \\
\text { Disagree }\end{array}$} & Disagree & Agree & \multicolumn{2}{c}{$\begin{array}{c}\text { Moderately } \\
\text { Agree }\end{array}$} & \multicolumn{2}{c}{$\begin{array}{c}\text { Strongly } \\
\text { Agree }\end{array}$} \\
\cline { 2 - 13 } & $n$ & $\%$ & $n$ & $\%$ & $n$ & $\%$ & $n$ & $\%$ & $n$ & $\%$ & $n$ & $\%$ \\
\hline Agent & 1.0 & 5.3 & 0.0 & 0.0 & 3.0 & 15.8 & 10.0 & 52.6 & 4.0 & 21.1 & 1.0 & 5.3 \\
Producer & 0.0 & 0.0 & 0.0 & 0.0 & 2.0 & 1.8 & 41.0 & 37.6 & 25.0 & 22.9 & 41.0 & 37.6 \\
\hline
\end{tabular}

\section{Comparison of the Offering of and Desire for Heifer Management Programs}

Nearly all dairy producers (96.3\%) agreed they desired heifer management programs while about three quarters of the Extension Agents (73.6\%) agreed to offering heifer management programs. Two Extension Agents (10.5\%) strongly agreed to offering heifer management programs while 40 producers (36.7\%) strongly agreed to desiring heifer management programs. Four agents (21.1\%) moderately agreed to offering heifer management programs and 25 producers (21.1\%) moderately agreed to desiring heifer 
programs. Eight agents (42.1\%) agreed to offering and 40 producers (36.7\%) agreed to desiring heifer management programs. One agent (5.3\%) strongly disagreed to offering heifer management programs. Four Extension Agents (21.1\%) disagreed to offering programs while only four producers (3.7\%) disagreed to desiring heifer management programs (see Table 30).

Table 30

Comparison of Agents and Producers on the Topic of Heifer Management Programs

\begin{tabular}{lccccccccccccc}
\hline & $\begin{array}{c}\text { Strongly } \\
\text { Disagree }\end{array}$ & $\begin{array}{c}\text { Moderately } \\
\text { Disagree }\end{array}$ & Disagree & & Agree & $\begin{array}{c}\text { Moderately } \\
\text { Agree }\end{array}$ & $\begin{array}{c}\text { Strongly } \\
\text { Agree }\end{array}$ \\
\cline { 2 - 14 } & $n$ & $\%$ & $n$ & $\%$ & $n$ & $\%$ & $n$ & $\%$ & $n$ & $\%$ & $n$ & $\%$ \\
\hline Agent & 1.0 & 5.3 & 0.0 & 0.0 & 4.0 & 21.1 & 8.0 & 42.1 & 4.0 & 21.1 & 2.0 & 10.5 \\
Producer & 0.0 & 0.0 & 0.0 & 0.0 & 4.0 & 3.7 & 40.0 & 36.7 & 25.0 & 22.9 & 40.0 & 36.7 \\
\hline
\end{tabular}

Comparison of Offering of and Desire for Forage Production Programs

Extension Agents were asked if they offered programs related to forage production and dairy producers were asked if they desired forage production programs. Three Extension Agents (15\%) disagreed that they offer forage management programs while only one producer (5\%) disagreed to desiring this program. Five agents (25\%) strongly agreed that they offered programs related to forage production while 41 producers (37.6\%) strongly agreed that they desired forage production programs. Three agents (15\%) moderately agreed that they offered programs related to forage production while 36 producers (33\%) moderately agreed that they desired forage production programs. Nine Extension Agents (45\%) agreed to offering forage production programs and 33 producers (30.3\%) agreed to desiring forage production programs. One agent 
(5\%) strongly disagreed to offering programs related to forage production. Two agents (10\%) disagreed to offering forage production programs while only three producers (2.8\%) disagreed to desiring forage production programs (see Table 31).

Table 31

Comparison of Agents and Producers on the Topic of Forage Production Programs

\begin{tabular}{lccccccccccccc}
\hline & $\begin{array}{c}\text { Strongly } \\
\text { Disagree }\end{array}$ & $\begin{array}{c}\text { Moderately } \\
\text { Disagree }\end{array}$ & Disagree & & Agree & $\begin{array}{c}\text { Moderately } \\
\text { Agree }\end{array}$ & $\begin{array}{c}\text { Strongly } \\
\text { Agree }\end{array}$ \\
\cline { 2 - 13 } & $n$ & $\%$ & $n$ & $\%$ & $n$ & $\%$ & $n$ & $\%$ & $n$ & $\%$ & $n$ & $\%$ \\
\hline Agent & 1.0 & 5.0 & 0.0 & 0.0 & 2.0 & 10.0 & 9.0 & 45.0 & 3.0 & 15.0 & 5.0 & 25.0 \\
Producer & 0.0 & 0.0 & 0.0 & 0.0 & 3.0 & 2.8 & 33.0 & 30.3 & 32.0 & 29.4 & 41.0 & 37.6 \\
\hline
\end{tabular}

Comparison of Offering of and Desire for Milking Management Programs

Five Extension Agents (26.4\%) disagreed that they offered milking management programs. Only one producer ( $0.9 \%)$ disagreed that they desired milking management programs. One Extension Agent (5.3\%) strongly agreed they offered milking management programs while 31 dairy producers (28.4\%) strongly agreed that they desired milking management programs. Four agents (21.1\%) moderately agreed to offering milking management programs while 36 producers (33\%) moderately agreed to desiring programs related to milking management. Nine Extension Agents (47.4\%) agreed they offered milking management programs and 41 dairy producers (37.6\%) agreed they desired milking management programs. One agent (5.3\%) strongly disagreed to offering milking management programs. Four Extension Agents (21.1\%) disagreed to offering and one producer ( $0.9 \%)$ disagreed to desiring milking management programs (see Table 32). 
Table 32

Comparison of Agents and Producers on the Topic of Milking Management Programs

\begin{tabular}{lccccccccccccc}
\hline & $\begin{array}{c}\text { Strongly } \\
\text { Disagree }\end{array}$ & \multicolumn{2}{c}{$\begin{array}{c}\text { Moderately } \\
\text { Disagree }\end{array}$} & Disagree & Agree & \multicolumn{2}{c}{$\begin{array}{c}\text { Moderately } \\
\text { Agree }\end{array}$} & \multicolumn{2}{c}{$\begin{array}{c}\text { Strongly } \\
\text { Agree }\end{array}$} \\
\cline { 2 - 12 } & $n$ & $\%$ & $n$ & $\%$ & $n$ & $\%$ & $n$ & $\%$ & $n$ & $\%$ & $n$ & $\%$ \\
\hline Agent & 1.0 & 5.3 & 0.0 & 0.0 & 4.0 & 21.1 & 9.0 & 47.4 & 4.0 & 21.1 & 1.0 & 5.3 \\
Producer & 0.0 & 0.0 & 0.0 & 0.0 & 1.0 & 0.9 & 41.0 & 37.6 & 36.0 & 33.0 & 31.0 & 28.4 \\
\hline
\end{tabular}

Comparison of Offerings of and Desire for Herd Health Programs

Extension Agents were asked if they offered programs related to herd health and dairy producers were asked if they desired herd health programs. Four agents (20\%) disagreed that they offered herd health programs while only one producer $(0.9 \%)$ disagreed that they desired this program. One agent (5\%) strongly agreed to offering herd health programs while 47 producers (43.1\%) strongly agreed to desiring herd health programs. Five agents (25\%) moderately agreed to offering and 31 producers (28.4\%) agreed they desire herd health programs. Ten agents (50\%) agreed they offer herd health programs and 30 producers (27.5\%) agreed to desiring them. One agent (5\%) strongly disagreed to offering herd health programs. Three Extension Agents (15\%) disagreed to offering and one producer (0.9\%) disagreed to desiring herd health programs (see Table 33). 
Table 33

Comparison of Agents and Producers on the Topic of Herd Health Programs

\begin{tabular}{lccccccccccccc}
\hline & $\begin{array}{c}\text { Strongly } \\
\text { Disagree }\end{array}$ & $\begin{array}{c}\text { Moderately } \\
\text { Disagree }\end{array}$ & Disagree & Agree & $\begin{array}{c}\text { Moderately } \\
\text { Agree }\end{array}$ & $\begin{array}{c}\text { Strongly } \\
\text { Agree }\end{array}$ \\
\cline { 2 - 13 } & $n$ & $\%$ & $n$ & $\%$ & $n$ & $\%$ & $n$ & $\%$ & $n$ & $\%$ & $n$ & $\%$ \\
\hline Agent & 1.0 & 5.0 & 0.0 & 0.0 & 3.0 & 15.0 & 10.0 & 50.0 & 5.0 & 25.0 & 1.0 & 5.0 \\
Producer & 0.0 & 0.0 & 0.0 & 0.0 & 1.0 & 0.9 & 30.0 & 27.5 & 31.0 & 28.4 & 47.0 & 43.1 \\
\hline
\end{tabular}

Comparison of Offerings of and Desire for Reproduction Programs

Almost all producers (99.1\%) agreed that they desired reproduction programs.

About three quarters of Extension Agents (78.9\%) agreed that they offered reproduction programs. Three Extension Agents (15.8\%) strongly agreed to offering reproduction programs while 50 producers (45.9\%) strongly agreed to desiring reproduction programs. Two agents (10.5\%) moderately agreed to offering and 28 producers (25.7\%) moderately agreed they desire reproduction programs. Ten Extension Agents (52.6\%) agreed they offer reproduction programs while 30 producers (27.5\%) agreed they desired reproduction programs. One Extension Agent (5.3\%) strongly disagreed to offering programs related to reproduction. Three agents (15.8\%) disagreed to offering reproduction programs one producer $(0.9 \%)$ disagreed to desiring reproduction programs (see Table 34). 
Table 34

Comparison of Agents and Producers on the Topic of Reproduction Management Programs

\begin{tabular}{lcccccccccccccc}
\hline & $\begin{array}{c}\text { Strongly } \\
\text { Disagree }\end{array}$ & $\begin{array}{c}\text { Moderately } \\
\text { Disagree }\end{array}$ & Disagree & Agree & \multicolumn{2}{c}{$\begin{array}{c}\text { Moderately } \\
\text { Agree }\end{array}$} & $\begin{array}{c}\text { Strongly } \\
\text { Agree }\end{array}$ \\
\cline { 2 - 13 } & $n$ & $\%$ & $n$ & $\%$ & $n$ & $\%$ & $n$ & $\%$ & $n$ & $\%$ & $n$ & $\%$ \\
\hline Agent & 1.0 & 5.3 & 0.0 & 0.0 & 3.0 & 15.8 & 10.0 & 52.6 & 2.0 & 10.5 & 3.0 & 15.8 \\
Producer & 0.0 & 0.0 & 0.0 & 0.0 & 1.0 & 0.9 & 30.0 & 27.5 & 28.0 & 25.7 & 50.0 & 45.9 \\
\hline
\end{tabular}

Comparison of Offerings of and Desire for Nutrient Management Programs

Extension Agents were asked if they offered nutrient management programs and dairy producers were asked if they had a desire for nutrient management programs. Seven agents (35\%) disagreed that they offered nutrient management programs while four producers (3.7\%) disagreed that they desire nutrient management programs. Four agents (20\%) strongly agreed to offering nutrient management programs and 31 producers (28.7\%) strongly agreed to desiring this type of program. Only two agents (10\%) moderately agreed they offer nutrient management programs while 21 producers $(19.4 \%)$ moderately agreed to desiring nutrient management programs. Seven Extension Agents (35\%) agreed to offering and 52 producers (48.1\%) agreed they desire nutrient management programs. One agent (5\%) strongly disagreed to offering nutrient management programs. Six agents (30\%) disagreed to offering and four producers (3.7\%) disagreed to desiring nutrient management programs (see Table 35). 
Table 35

Comparison of Agents and Producers on the Topic of Nutrient Management Programs

\begin{tabular}{lccccccccccccc}
\hline & $\begin{array}{c}\text { Strongly } \\
\text { Disagree }\end{array}$ & $\begin{array}{c}\text { Moderately } \\
\text { Disagree }\end{array}$ & Disagree & Agree & \multicolumn{2}{c}{$\begin{array}{c}\text { Moderately } \\
\text { Agree }\end{array}$} & $\begin{array}{c}\text { Strongly } \\
\text { Agree }\end{array}$ \\
\cline { 2 - 13 } & $n$ & $\%$ & $n$ & $\%$ & $n$ & $\%$ & $N$ & $\%$ & $n$ & $\%$ & $n$ & $\%$ \\
\hline Agent & 1.0 & 5.0 & 0.0 & 0.0 & 6.0 & 30.0 & 7.0 & 35.0 & 2.0 & 10.0 & 4.0 & 20.0 \\
Producer & 0.0 & 0.0 & 0.0 & 0.0 & 4.0 & 3.7 & 52.0 & 48.1 & 21.0 & 19.4 & 31.0 & 28.7 \\
\hline
\end{tabular}

\section{Comparison of Offerings of and Desire for Dairy Quality Assurance Programs}

Most dairy producers (93.5\%) were in some form of agreement when it came to desiring dairy quality assurance programs while only about two thirds of Extension Agents (63.1\%) were in some form of agreement to offering dairy quality assurance programs. Twenty-four dairy producers (22.2\%) strongly agreed they desire dairy quality assurance programs. Two Extension Agents (10.5\%) moderately agreed to offering and 21 producers (19.4\%) moderately agreed they desired dairy quality assurance programs. Ten agents (52.6\%) agreed they offered dairy quality assurance programs and 56 producers (51.9\%) agreed to desiring these programs. One Extension Agent (5.3\%) strongly disagreed to offering dairy quality assurance programs and one producer $(0.9 \%)$ strongly disagreed to desiring dairy quality assurance programs. One producer $(0.9 \%)$ moderately disagreed to desiring dairy quality assurance programs. Six Extension Agents (31.6\%) disagreed to offering and five producers (4.6\%) disagreed to desiring dairy quality assurance programs (see Table 36). 
Table 36

Comparison of Agents and Producers on the Topic of Dairy Quality Assurance Programs

\begin{tabular}{lccccccccccccc}
\hline & $\begin{array}{c}\text { Strongly } \\
\text { Disagree }\end{array}$ & \multicolumn{2}{c}{$\begin{array}{c}\text { Moderately } \\
\text { Disagree }\end{array}$} & Disagree & Agree & \multicolumn{2}{c}{$\begin{array}{c}\text { Moderately } \\
\text { Agree }\end{array}$} & $\begin{array}{c}\text { Strongly } \\
\text { Agree }\end{array}$ \\
\cline { 2 - 13 } & $n$ & $\%$ & $n$ & $\%$ & $n$ & $\%$ & $n$ & $\%$ & $n$ & $\%$ & $n$ & $\%$ \\
\hline Agent & 1.0 & 5.3 & 0.0 & 0.0 & 6.0 & 31.6 & 10.0 & 52.6 & 2.0 & 10.5 & 0.0 & 0.0 \\
Producer & 1.0 & 0.9 & 1.0 & 0.9 & 5.0 & 4.6 & 56.0 & 51.9 & 21.0 & 19.4 & 24.0 & 22.2 \\
\hline
\end{tabular}




\section{CHAPTER V}

Summary, Conclusions, and Recommendations

\section{Purpose and Objectives}

The purpose of this study was to determine if information from Extension Agents is getting to the dairy producers, through appropriate advertising of programs as well as the information disseminated during programs. In addition what are Extension Agents doing to reach the special populations (e.g. Amish, Hispanic, disabled) of dairy producers in their county?

The primary objective of this study was to compare the services Extension Agents are providing within a county with the services producers of the county would like to have. The research focused on areas of advertising for programs, information transfer during programs, and program offerings.

\section{Research Questions}

1. How do Extension Agents in Pennsylvania advertise their extension programs?

2. How do dairy producers in Pennsylvania prefer to learn about extension programs?

3. What methods do Pennsylvania Extension Agents use to teach their programs?

4. What teaching methods do Pennsylvania dairy producers prefer to be used during programs?

5. Are Pennsylvania Extension Agents connecting with dairy producers in their county through advertising and information transfer during programs as well as types of programs offered? 
6. Are Pennsylvania Extension Agents targeting programs to the special populations (e.g. Amish, Hispanic, disabled) in their county and how are they making adjustment to accommodate them in their programs?

\section{Summary}

The sample population for this study consisted of 275 Pennsylvania dairy producers randomly selected from the Lancaster County Dairy Herd Improvement Association's 2005-2006 Annual Report and the 30 Extension Agents who serve these producers. Of the 30 agent surveys 25 were returned (80.6\%). Of the 275 dairy producer surveys 114 were returned (41.5\%). Research Question One - "How do Extension Agents in Pennsylvania Advertise for their Programs?”

Extension Agents in Pennsylvania advertise for their programs using a variety of methods. The top three methods were determined by adding the percentages of strongly agree and moderately agree to determine which method was most agreed on. The top three methods used by Extension Agents were mail, pamphlets and flyers. All three of these methods received the same percentage of $75 \%$. The next most popular method was word of mouth followed by the newspaper. The least popular method of advertisement by Extension Agents was the use of television.

Research Question Two - "How do Dairy Producers in Pennsylvania Prefer to Learn about Extension Programs?”

Dairy producers in Pennsylvania preferred mail as their top method of advertisement for dairy programs. Producer’s second preference was pamphlets followed 
by flyers. The least popular methods of advertisement of Extension dairy programs by dairy producers were the use of television and Internet.

Research Question Three - "What Methods do Extension Agents use to Teach their Programs?”

The top three methods utilized by Extension Agents to teach programs were demonstrations, computer software and fact sheets all receiving the same percentage score of $45 \%$. These were followed by videos/DVDs, group work and pamphlets in second. The least most popular method was the use of books.

Research Question Four -"What Teaching Methods do Dairy Producers Prefer be Used during Programs?”

The top teaching methods preferred by dairy producers to be used at dairy programs was the use of demonstrations. The second most popular teaching method was the use of videos and/or DVD's followed by fact sheets in third. The least popular teaching method was the use of the Internet.

Research Question 5 - “Are Pennsylvania Extension Agents connecting with Dairy Producers in their County through Advertising and Information Transfer During Programs as Well as Types of Programs Offered?”

Even though the levels of agreement are different, Extension Agents and dairy producers appear to be connecting very well when it comes to methods of advertisement. They both agreed that their top choices are through mail, pamphlets and flyers. They also both placed the use of television at the bottom of their list of advertisement methods with dairy producers also placing the Internet at the bottom of their lists. 
With regard to teaching methods, the two groups were in disagreement. Extension Agents and dairy producers were in agreement that demonstrations were the top choice for teaching methods. However, Extension Agents preferred lectures and books at the same rate as demonstrations. Dairy producers placed videos and/or DVD's in second and fact sheets in third.

The programs offered by Extension Agents and those preferred by dairy producers appear to be different. The topic most offered by Extension Agents was forage production programs. This was followed by heifer management, financial management and barn construction programs. However, dairy producers preferred reproduction programs, herd health, milking management and dairy nutrition programs. Research Question Six - “Are Extension Agents Targeting Programs to the Special Populations (e.g. Amish, Hispanic, Disabled) in their County and how are they Making Adjustments to Accommodate them in their Programs?”

Extension Agents in Pennsylvania expressed that Amish, Hispanic and Disabled producers reside in their counties. In addition to these populations agents also noted having Mennonite producers in their counties. Only one agent noted that Amish producers do not attend his/her programs. All other agents expressed that Amish, Hispanic and disabled producers attend their programs as well as the general public.

Most Extension Agents felt that they made efforts to advertise their programs to reach Amish and disabled producers. In addition to these producers efforts are made to advertise to Mennonite producers as well as the general public. Most Extension Agents do not make special efforts to advertise to the Hispanic producers. 
Most Extension Agents adjust their programs to accommodate Amish producers. In addition to Amish producers, agents accommodate Mennonite producers. Most agents do not adjust their programs to accommodate Hispanic or disabled producers.

\section{Conclusions:}

Based on the results of this study, the following conclusions were made

1. Extension Agents and dairy producers in Pennsylvania agree on methods of advertisement for programs.

2. Extension Agents and dairy producers both prefer demonstrations as their top teaching method.

3. Extension Agents in Pennsylvania offer all programs that dairy producers desire but not as consistently as the producers would like.

4. Amish, Hispanic and disabled producers live in all counties noted in this study as well as Mennonite producers.

5. Amish, Hispanic and disabled producers attend Extension programs.

6. Extension Agents make efforts to advertise to Amish and disabled as well as Mennonite and general producers in their counties.

7. Extension Agents do not make efforts to advertise to the Hispanic producers in their counties.

8. Extension Agents adjust their programs to accommodate Amish producers as well as Mennonite producers.

9. Extension Agents do not adjust their programs to accommodate Hispanic or disabled producers in their counties. 


\section{Recommendations}

The researcher makes the following recommendations based on the results of this study:

1. Extension Agents in Pennsylvania should advertise for dairy programs using mail, pamphlets and flyers.

2. Extension Agents in Pennsylvania should use demonstrations as a main teaching method during programs.

3. Extension Agents in Pennsylvania should conduct needs assessments to determine what type of dairy programs is most desired by the clientele in their county.

4. Extension Agents in Pennsylvania should explore the best means to advertise to Amish, disabled and Mennonite producers.

5. Extension Agents in Pennsylvania should consider means to advertise to and accommodate the 349 Hispanic producers in the state.

6. Extension Agents should continue to make adjustments their programs to accommodate Amish and Mennonite producers in areas of large Amish and Mennonite populations.

7. Extension Agents should adjust their programs to accommodate the disabled producers in Pennsylvania.

8. This study should be replicated involving all Extension Agents and dairy producers in Pennsylvania.

9. This study should be replicated to include Extension Agents and dairy producers regionally or nationally.

10. Research should be conducted with Extension Agents and other producer groups. 


\section{REFERENCES}

2002 Census of Agriculture (2002). Retrieved January 16, 2008 from

http://www.nass.usda.gov/census/census02/volume1/pa/index1.htm

The Amish(2007). Retrieved February 20, 2008 from

http://www.phmc.state.pa.us/ppet/amish/page1.asp?secid=31

The Amish (2008). The Amish and Technology. Retrieved February 20, 2008 from http://www.padutchcountry.com/our_world/the_amish.asp

Ary, D., Jacobs, L. C., Razavieh, A., \& Sorenson, C. (2006). Introduction to research in education.( $7^{\text {th }}$ ed.). Belmont, Ca: Thomson Wadsworth.

Brown, B. L. (2003). Teaching style vs. learning style myths and realities. Columbus: Center on Education and Training for Employment

Chizari, M., Karbasioun, M., \& Lindner, J.R. (1998) Obstacles facing extension agents in the development and delivery of extension educational programs for adult farmers in the province of Esfahan, Iran. Journal of Agricultural Education, 39(1), 48-54.

Dillman, D.A. (2007). Mail and internet surveys: the tailored design method ( ${ }^{\text {nd }}$ ed.). New Jersey: John Wiley.

Gamon, J., Harrold, N., \& Creswell, J. (1994). Educational delivery methods to encourage adoption of sustainable agricultural practices. Journal of Agricultural Education, 35(1), 38-42.

Iddings, R. K., Apps, J. W. (1990). What influences farmer's computer use? Journal of Extension. 28(1). Retrieved January 17, 2008 from http://www.joe.org/joe/1990spring/a4.html

Krejcie, R. V. \& Morgan, D. W. (1970). Determining sample size for research activities. Educational and Psychological Measurement, 30, 607-610.

National Agricultural Statistics Service (2008). 2007 milk production in Pennsylvania down slightly from 2006. Retrieved April 14, 2008 from http://www.nass.usda.gov/Statistics_by_State/Pennsylvania/Publications/Survey_ Results/milkprod_annual.pdf

National Language and Literacy Institute of Australia. (1999). Adult learning. ARIS information sheet. Victoria, Australia. 
Neehouse, L. M. (2005). Mass communication delivery methods used and possessed by Extension Agents in West Virginia. Unpublished master's thesis, West Virginia University, Morgantown, WV. Retrieved February 20, 2008 from https://eidr.wvu.edu/files/3923/Neehouse_Lisa_thesis.pdf

Nehiley, J. M. (2001). Developing a simple four-step marketing plan for Extension programs. Journal of Extension. 39(2). Retrieved January 17,2008 from http://www.joe.org/joe/2001april/iw3.html

Peters, B. A. (1998). Measuring the quality of communication linkages between farmers and the agricultural agencies responsible for the diffusion of innovations in the south west province of Cameroon. Unpublished master's thesis, Texas A\&M University, College Station, TX. Retrieved January 27, 2008 from http://www.eric.ed.gov/

Rexroad, T. (2002). Evaluation of marketing methods used to promote Extension programs as perceived by Master Gardeners in West Virginia (Masters thesis, West Virginia University 2002). Retrieved November 15, 2007 from https://eidr .wvu.edu/files/2337/rexroad_tiffany_thesis.pdf

Richardson, J. G. \& Mustian, R. D. (1988). Preferred methods of delivery of technological information by the North Carolina Agriculutral Extension Service: opinions of agricultural producers who use Extension information. North Carolina: North Carolina State University. Retrieved February 20, 2008 from http://www.eric.ed.gov/ERICDocs/data/ericdocs2sql/content_storage_01/0000019 b/80/1d/83/dc.pdf

Riesenberg, L. E., \& Gor, C. O. (1989). Farmers’ preferences for methods of receiving information on new or innovative farming practices. Journal of Agricultural Education, 30(3), 7-13. Retrieved January 10, 2008 from http://pubs.aged.tamu.edu/jae//pdf/vol30/30-03-07.pdf

Robinson, J. P., Shaver P. R., \& Wrightsman, L. S. (1991). Measures of personality and social psychological attitudes (pp. 1-16) New York: Academic Press.

Seevers, B., Graham, D., \& Conklin, N. (2007). Education through cooperative extension $\left(2^{\text {nd }}\right.$ ed.). Columbus: Curriculum Materials Service. p 1-3.

Smith-Lever Act. Retrieved February 20, 2008 from: http://www.higher-ed.org/resources/smith.htm

Suvedi, M., Lapinski, M. K. \& Campo, S. (2000). Farmer's perspectives of Michigan State University Extension: trends and lessons from 1996 and 1999. Journal of Extension. 38(1). Retrieved January 15, 2008 from http://www.joe.org/joe/2000february/a4.html 
Warner, P. D., Christenson, J. A., Dillman, D. A. \& Salant, P. (1996). Public perception of Extension. Journal of Extension. 34(4). Retrieved January 15, 2008 from http://www.joe.org/joe/1996august/a1.html 
APPENDICES 
APPENDIX A

First Mailing Cover-Letters 
January 3, 2008

Dear County Extension Agent:

Pennsylvania is the number four producer of dairy products in the United States. There are many things that go into running a successful dairy farm such as cow and heifer management and nutrition. You are a valuable resource to your county and you may or may not be being utilized to the extent of your potential.

I am Carrie Nelson, a graduate student in Agriculture and Extension Education at West Virginia University and a recent graduate of Penn State. Under the direction of my advisor, Dr. Deborah A. Boone, I am conducting a study to determine the amount and type of information transfer between extension agents and dairy producers across the state of Pennsylvania. The results of this study will be used to prepare a thesis to partially fulfill the requirements for a Masters of Science degree in Agricultural and Extension Education.

Your participation in this study is solely voluntary. You may stop filling out this survey at any time but your completion of this survey is crucial to the success of this study. The survey should only take about 15 minutes and your results will be held as confidential as possible. You will notice a code number at the bottom left hand corner of your return envelope. This number is only used to keep track of non-respondents and will be destroyed before that data is analyzed making it in no way possible to track your individual response.

Please place the completed questionnaire in the self addressed pre paid envelope and drop it into the mail box by January 18, 2008. A ruler was sent with this survey as a token of appreciation for you time and efforts.

Sincerely:

Carrie Nelson

Graduate Student
Deborah A. Boone, Ph. D Assistant Professor 
January 3, 2008

Dear Pennsylvania Dairy Producer:

You are one of the reasons that Pennsylvania is the number four producer of dairy products in the United States. There are many things that go into running a successful dairy farm such as cow and heifer management and nutrition. At some point in your career I am sure that you have had questions about your farm. To answer these questions you may have turned to your nutritionist, veterinarian or county extension agent.

I am Carrie Nelson, a graduate student in Agricultural and Extension Education at West Virginia University and a recent graduate of Penn State. Under the direction of my advisor, Dr. Deborah A. Boone, I am conducting a study to determine the amount and type of information transfer between county extension agents and dairy producers across the state of Pennsylvania. The results of this study will be used to prepare a thesis to partially fulfill the requirements for a Masters of Science degree in Agricultural and Extension Education. By finding out your attitudes towards information transfer by the extension agent, the extension agents will be able to better serve you, the dairy producer.

Your participation in this study is solely voluntary. You may stop filling out this survey at any time but your completion of this survey is crucial to the success of this study. The survey should only take about 15 minutes and your results will be held as confidential as possible. You will notice a code number at the bottom left hand corner of your return envelope. This number is only used to keep track of non-respondents and will be destroyed before that data is analyzed making it in no way possible to track your individual response.

Please place the completed questionnaire in the self addressed pre paid envelope and drop it into the mail box by January 18, 2008. A magnet was sent with this survey as a token of appreciation for you time and efforts.

Sincerely:

Carrie Nelson

Graduate Student
Deborah A. Boone, Ph. D

Assistant Professor 
APPENDIX B

Second Mailing Cover Letters 
January 25, 2008

Dear County Extension Agent:

On January 3 you were sent a survey regarding your dairy programs. As of today we have not received your reply; we are sending a second copy of the survey and hope you will complete and return. If you have already returned the first survey there is no need to complete this one, we sincerely appreciate your participation.

Pennsylvania is the number four producer of dairy products in the United States. There are many things that go into running a successful dairy farm such as cow and heifer management and nutrition. You are a valuable resource to your county and you may or may not be being utilized to the extent of your potential.

I am Carrie Nelson, a graduate student in Agriculture and Extension Education at West Virginia University and a recent graduate of Penn State. Under the direction of my advisor, Dr. Deborah A. Boone, I am conducting a study to determine the amount and type of information transfer between extension agents and dairy producers across the state of Pennsylvania. The results of this study will be used to prepare a thesis to partially fulfill the requirements for a Masters of Science degree in Agricultural and Extension Education. West Virginia University's IRB acknowledgement of this study is on file.

Your participation in this study is solely voluntary. You may stop filling out this survey at any time but your completion of this survey is crucial to the success of this study. The survey should only take about 15 minutes and your responses will be held as confidential as possible. You will notice a code number in the upper left hand corner of your return envelope. This number is only used to keep track of non-respondents and will be destroyed before that data is analyzed making it in no way possible to track your individual response.

Please place the completed questionnaire in the self addressed pre paid envelope and drop it into the mail box by February 10, 2008. Thank you, we sincerely appreciate your time and efforts.

Sincerely:

Carrie Nelson

Graduate Student
Deborah A. Boone, Ph.D. Assistant Professor 
January 25, 2008

Dear Pennsylvania Dairy Producer:

On January 3 you were sent a survey regarding your views on your county's dairy extension agent and dairy programs. As of today we have not received your reply; we are sending a second copy of the survey and hope you will complete and return. If you have already returned the first survey there is no need to complete this one, we sincerely appreciate your participation.

You are one of the reasons that Pennsylvania is the number four producer of dairy products in the United States. There are many things that go into running a successful dairy farm such as cow and heifer management and nutrition. At some point in your career I am sure that you have had questions about your farm. To answer these questions you may have turned to your nutritionist, veterinarian or county extension agent.

I am Carrie Nelson, a graduate student in Agricultural and Extension Education at West Virginia University and a recent graduate of Penn State. Under the direction of my advisor, Dr. Deborah A. Boone, I am conducting a study to determine the amount and type of information transfer between county extension agents and dairy producers across the state of Pennsylvania. The results of this study will be used to prepare a thesis to partially fulfill the requirements for a Masters of Science degree in Agricultural and Extension Education. West Virginia University's IRB acknowledgement of this study is on file. By finding out your attitudes towards information transfer by the extension agent, the extension agents will be able to better serve you, the dairy producer.

Your participation in this study is solely voluntary. You may stop filling out this survey at any time but your completion of this survey is crucial to the success of this study. The survey should only take about 15 minutes and your responses will be held as confidential as possible. You will notice a code number in the upper left hand corner of your return envelope. This number is only used to keep track of non-respondents and will be destroyed before that data is analyzed making it in no way possible to track your individual response.

Please place the completed questionnaire in the self addressed pre paid envelope and drop it into the mail box by February 10, 2008. Thank you, we sincerely appreciate your time and efforts.

Sincerely:

Carrie Nelson

Graduate Student

Deborah A. Boone, Ph.D. Assistant Professor 
APPENDIX C

Follow Up Card and Email 
On January 3, 2008 you were sent a survey regarding dairy programs you provide for local producers. On January 25, 2008 you were sent a second copy of the survey. As of today I have not received your response. Because you are such a vital resource to the dairy producers of Pennsylvania it is important to obtain information about your dairy programs. Your responses will help to better serve the dairy producers of your area as well as producers throughout the state. Your response is crucial to the success of this study so please take the time to complete the survey and return it no later than February 15, 2008. If you have already completed and returned the survey please disregard this card. Thank you for your time and effort to make my study a success.

If you have any questions please contact me at:

Carrie Nelson

Agriculture and Extension Education

Davis College of Agriculture, Forestry and Consumer Sciences

2050 Agriculture Sciences Building

P.O. Box 6108

Morgantown, WV 26505

(412) 427-6465

cnelso17@mix.wvu.edu 
On January 3, 2008 you were sent a survey regarding your views toward your county's dairy agent(s) and their programs. On January 25, 2008 you were sent a second copy of the survey. As of today I have not received your response. Because you are such a vital role in Pennsylvania's dairy industry it is important to determine your views toward your dairy agent and their programs. Your responses will be used to help Pennsylvania dairy agents better meet your needs as well as the needs of dairy producers across the state. Your response is crucial to the success of this study so please take the time to complete the survey and return it no later than February 15, 2008. If you have already completed and returned the survey please disregard this card. Thank you for your time and effort to make my study a success.

If you have any questions please contact me at:

Carrie Nelson

Agriculture and Extension Education

West Virginia University

P.O. Box 6108

Morgantown, WV 26506

(304) 293-4832 ext. 4477

cnelso17@mix.wvu.edu 
APPENDIX D

Extension Agent Questionnaire 


\section{Evaluation of Information Transfer Between Extension Agents and Dairy Producers in Pennsylvania}

Extension Agent Survey

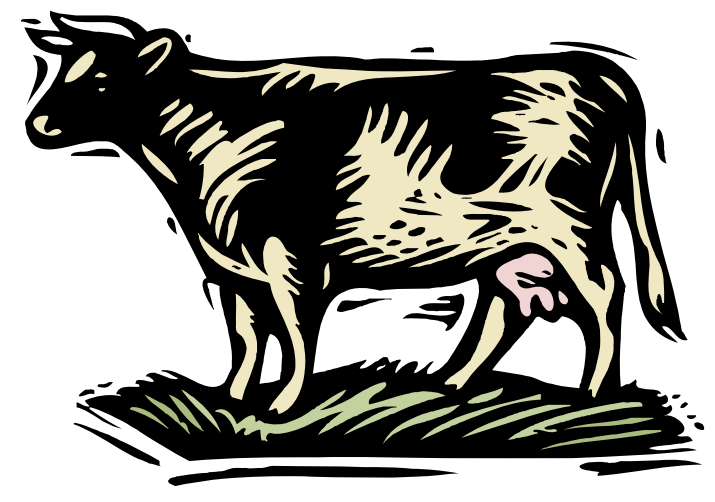

Carrie Nelson

Agriculture and Extension Education

Davis College of Agriculture, Forestry and Consumer Sciences West Virginia University

Morgantown, WV 26505 


\section{Evaluation of Information Transfer Between Extension Agents and Dairy Producers in Pennsylvania}

Instructions: Using the following Likert scale, rate the following statements about your county extension office's dairy agents and programs. Indicate your opinion by circling the letters that best corresponds to your response. SDStrongly Disagree, MD- Moderately Disagree, D- Disagree, A- Agree, MAModerately Agree, SA- Strongly Agree.

\begin{tabular}{|c|c|c|c|c|c|c|}
\hline & 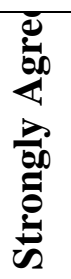 & 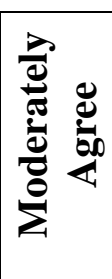 & 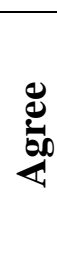 & 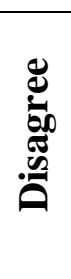 & 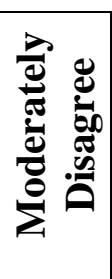 & 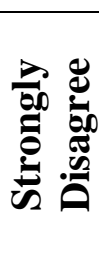 \\
\hline 1. I offer programs in dairy production. & SA & MA & $\mathrm{A}$ & $\mathrm{D}$ & MD & SD \\
\hline $\begin{array}{l}\text { 2. I am able to answer most questions about } \\
\text { dairy production. }\end{array}$ & SA & MA & A & $\mathrm{D}$ & MD & SD \\
\hline $\begin{array}{l}\text { 3. I return producer's calls/emails quickly and } \\
\text { efficiently. }\end{array}$ & SA & MA & A & $\mathrm{D}$ & MD & SD \\
\hline 4. I am a reliable source for dairy questions. & SA & MA & A & $\mathrm{D}$ & MD & SD \\
\hline $\begin{array}{l}\text { 5. The majority of dairy producers in my } \\
\text { county attend my programs. }\end{array}$ & SA & MA & A & $\mathrm{D}$ & MD & SD \\
\hline $\begin{array}{l}\text { 6. The new and innovative practices that I } \\
\text { teach are readily accepted. }\end{array}$ & SA & MA & A & $\mathrm{D}$ & MD & SD \\
\hline
\end{tabular}




\begin{tabular}{|c|c|c|c|c|c|c|}
\hline & 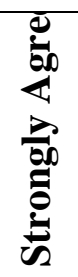 & 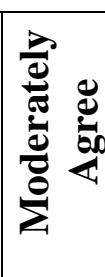 & 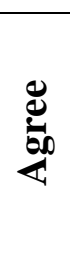 & 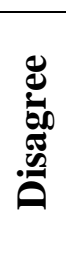 & 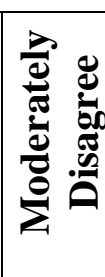 & 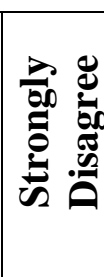 \\
\hline \multicolumn{7}{|c|}{ I use the following methods to advertise for my dairy programs: } \\
\hline 7. email & SA & MA & A & $\mathrm{D}$ & MD & SD \\
\hline 8. mail & SA & MA & A & $\mathrm{D}$ & MD & SD \\
\hline 9. pamphlets & SA & MA & A & $\mathrm{D}$ & MD & SD \\
\hline 10. fliers & SA & MA & A & $\mathrm{D}$ & MD & SD \\
\hline 11. word of mouth & SA & MA & A & $\mathrm{D}$ & MD & SD \\
\hline 12. exhibits & SA & MA & A & $\mathrm{D}$ & MD & SD \\
\hline 13. radio & SA & MA & A & $\mathrm{D}$ & MD & SD \\
\hline 14. farm visits & SA & MA & A & $\mathrm{D}$ & MD & SD \\
\hline 15. television & SA & MA & A & $\mathrm{D}$ & MD & SD \\
\hline 16. internet & SA & MA & A & $\mathrm{D}$ & MD & SD \\
\hline 17. newspaper & SA & MA & $\mathrm{A}$ & $\mathrm{D}$ & MD & SD \\
\hline 18. Other (please specify): & SA & MA & A & $\mathrm{D}$ & MD & SD \\
\hline
\end{tabular}




\begin{tabular}{|c|c|c|c|c|c|c|}
\hline & 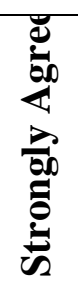 & 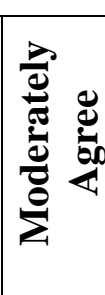 & مِّ & 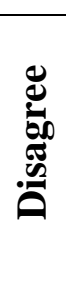 & 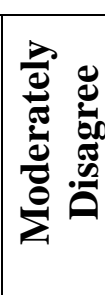 & 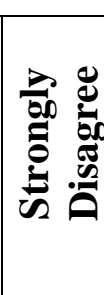 \\
\hline \multicolumn{7}{|c|}{ I use the following teaching methods to deliver dairy programs: } \\
\hline 19. demonstrations & SA & MA & A & $\mathrm{D}$ & MD & SD \\
\hline $\begin{array}{l}\text { 20. teaching and/or demonstrating computer } \\
\text { software }\end{array}$ & SA & MA & A & $\mathrm{D}$ & MD & SD \\
\hline 21. lectures & SA & MA & A & $\mathrm{D}$ & MD & SD \\
\hline 22. pamphlets & SA & MA & A & $\mathrm{D}$ & MD & SD \\
\hline 23. internet & SA & MA & A & $\mathrm{D}$ & MD & SD \\
\hline 24. showing videos and/or DVDs & SA & MA & A & $\mathrm{D}$ & MD & SD \\
\hline 25. audio cassettes/CDs & SA & MA & A & $\mathrm{D}$ & MD & SD \\
\hline 26. group work & SA & MA & A & $\mathrm{D}$ & MD & SD \\
\hline 27. fact sheets & SA & MA & A & $\mathrm{D}$ & MD & SD \\
\hline 28. books & SA & MA & A & $\mathrm{D}$ & MD & SD \\
\hline 29. Other (please specify): & SA & MA & A & $\mathrm{D}$ & MD & SD \\
\hline
\end{tabular}




\begin{tabular}{|c|c|c|c|c|c|c|}
\hline & 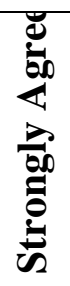 & 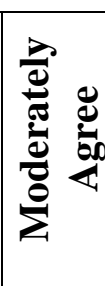 & 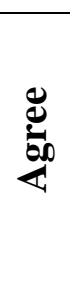 & 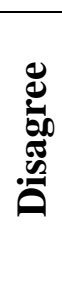 & 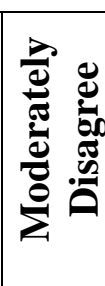 & 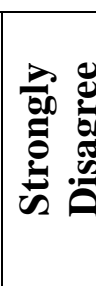 \\
\hline \multicolumn{7}{|c|}{ I offer dairy programs related to: } \\
\hline 30. Dairy Nutrition & SA & MA & A & $\mathrm{D}$ & MD & SD \\
\hline 31. Heifer Management & SA & MA & A & $\mathrm{D}$ & MD & SD \\
\hline 32. Financial Management & SA & MA & A & $\mathrm{D}$ & MD & SD \\
\hline 33. Forage Production & SA & MA & A & $\mathrm{D}$ & MD & SD \\
\hline 34. Milking Management & SA & MA & A & $\mathrm{D}$ & MD & SD \\
\hline 35. Herd Health & SA & MA & A & $\mathrm{D}$ & MD & SD \\
\hline 36. Reproduction & SA & MA & A & $\mathrm{D}$ & MD & SD \\
\hline 37. Nutrient Management & SA & MA & A & $\mathrm{D}$ & MD & SD \\
\hline 38. Barn Construction & SA & MA & A & $\mathrm{D}$ & MD & SD \\
\hline 39. Record Keeping & SA & MA & A & $\mathrm{D}$ & MD & SD \\
\hline 40. Dairy Quality Assurance & SA & MA & A & $\mathrm{D}$ & MD & SD \\
\hline 41. Other (please specify): & SA & MA & A & $\mathrm{D}$ & MD & SD \\
\hline
\end{tabular}


Instructions: Answer the following questions to the best of your ability.

42. My county contains producers of the following populations (check all that apply) a. Amish

b. Hispanic

c. Handicapped

d. Other (please specify:

43. Producers of the following population do not attend my programs (check all that apply)
a. Amish
b. Hispanic
c. Handicapped
d. Other (please specify:

44. I make an effort to advertise for my programs to producers of the following populations (check all that apply)
a. Amish
b. Hispanic
c. Handicapped
d. Other (please specify:

45. I adjust my programs to accommodate the following special populations (check all that apply)
a. Amish
b. Hispanic
c. Handicapped
d. Other (please specify:

46. Where do you feel that dairy producers in your county get answers to their dairy production questions? (Rank with 1 being the most used, 2 being the second most used and 3 being the third most used)

a. County Extension Agent

b. Farm Nutritionist

c. Veterinarian

d. Neighbor

e. Farm Store Employee

f. Other: 
47. How many dairy extension programs do you offer per year? (check one)

a. 0

b. 1-2

c. 3-4

d. 5 or more

48. What is the average dairy herd size per farm in your county? (check one)

a. 1-20

b. $21-40$

c. $41-60$

d. $61-80$

e. $81-100$

f. 101 or more

49. What is the average age of dairy producers within your county? (check one)

a. Younger than 20 years

b. 20-29 years

c. 30-39 years

d. 40-49 years

e. 50-59 years

f. 60 or older years 


\section{Comments:}

If you have any questions regarding this survey feel free to email me at cnelso17@mix.wvu.edu.

Thank yow for taking the lime and effort to complete this survey. 


\section{APPENDIX E}

Extension Agent Open Ended Responses 


\section{Open-ended Responses}

Question 29: "What other teaching methods do you use during dairy programs?”

\section{Responses:}

Podcasts

Question 41: "What other dairy programs do you offer?"

\section{Responses}

Valve Added Production

Market Outlook

Meat Quality Assurance

Farm Succession

Composting

Fly Control

Risk Management

Mortality

Rat Control

Ag Labor Management

Not every year but over a period of time.

Question 42: "My county contains producers of the following populations:” Responses:

I have surveyed the county and found no hispanic dairy farmers. there are hispanic dairy workers.

Mennonite

General Public 
White Americans

English

None Available (2)

Question 43: "Producers of the following population do no attend my programs"

Responses

General Public

None Available (2)

Question 44: "I make and effort to advertise for my programs to producers of the following populations”

Responses:

All reasonable effort is employed

Mennonite

General Public

All

English

NA

Question 45: “I adjust my programs to accommodate the following special populations”

Responses:

Limited Population

Mennonite

All

NA 
Question 46: "Where do you feel that dairy producers in your county get answers to their dairy production questions?”

Responses:

They may get answers but was it a good answer?

Company’s Technical Service Expert employed by businesses serving the dairy

industry

AI Tech

Question 47: "How many dairy extension programs do you offer per year?”

Responses:

Do you mean meetings?

0-3+ Newsletters 
APPENDIX F

Extension Agent Comments 


\section{Comments}

Responses:

Lancaster County is different from the reset of Pennsylvania due to the size of the industry. Therefore, my responses are likely different.

I'm obviously not the dairy educator! We have gone thru 5 staff in that position in 11 years. We've got an admin. supervisory problem here, not a program delivery problem.

I at one time served as dairy educator but with a change in program responsibilities I refer calls to a regional dairy educator.

I do not work directly w/ dairy producers.

As I began to answer these questions I feel my input would skew your results. My role is mostly administrative w/ minimal dairy programming. Best of luck.

Have you heard of survey monkey.com? I'm a professional. Don't waste my time with a milk promotion ruler. I found you ranking scale confusing and you directions state N/A, but you didn't have a N/A column.

Use of Internet video conference technology

I only work with 4-H Dairy-not adults 
I do not have a formal dairy program. Only a few dairies left in the county and I work with them one-on-one upon request. 
APPENDIX G

Dairy Producer Questionnaire 


\title{
Evaluation of Information Transfer Between Extension Agents and Dairy Producers in Pennsylvania
}

\author{
Dairy Producer Survey
}

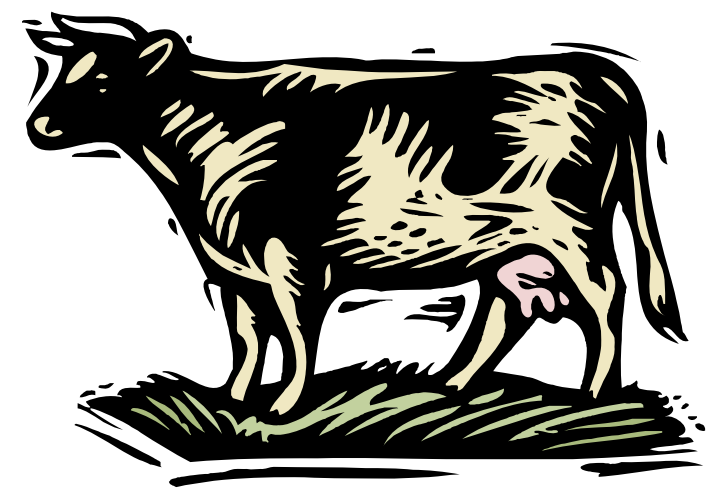

\author{
Carrie Nelson \\ Agriculture and Extension Education \\ Davis College of Agriculture, Forestry and Consumer Sciences \\ West Virginia University \\ Morgantown, WV 26505
}




\section{Evaluation of Information Transfer Between Extension Agents and Dairy Producers in Pennsylvania}

Instructions: Using the following Likert scale, rate the following statements about your county extension office's dairy agents and programs. Indicate your opinion by circling the letters that best corresponds to your response. SDStrongly Disagree, MD- Moderately Disagree, D- Disagree, A- Agree, MAModerately Agree, SA- Strongly Agree.

\begin{tabular}{|c|c|c|c|c|c|c|}
\hline & 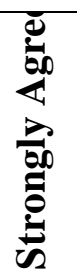 & 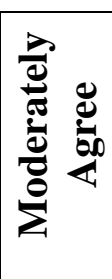 & 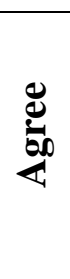 & 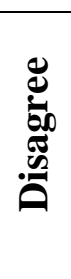 & 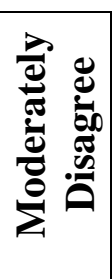 & 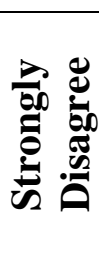 \\
\hline $\begin{array}{l}\text { 1. My County Extension Office offers } \\
\text { programs in dairy production. }\end{array}$ & SA & MA & A & D & MD & SD \\
\hline $\begin{array}{l}\text { 2. My County Extension Office is able to } \\
\text { answer most of my questions about dairy } \\
\text { production. }\end{array}$ & SA & MA & A & $\mathrm{D}$ & MD & SD \\
\hline $\begin{array}{l}\text { 3. My County Extension Office returns my } \\
\text { calls/emails quickly and efficiently. }\end{array}$ & SA & MA & A & $\mathrm{D}$ & MD & SD \\
\hline $\begin{array}{l}\text { 4. My County Extension Office is a reliable } \\
\text { source for my dairy questions. }\end{array}$ & SA & MA & A & $\mathrm{D}$ & MD & SD \\
\hline $\begin{array}{l}\text { 5. I am willing to attend extension programs } \\
\text { offered by my county. }\end{array}$ & SA & MA & A & $\mathrm{D}$ & MD & SD \\
\hline $\begin{array}{l}\text { 6. I am willing to accept and use new practices } \\
\text { learned at extension programs. }\end{array}$ & SA & MA & A & D & $\mathrm{MD}$ & SD \\
\hline
\end{tabular}




\begin{tabular}{|c|c|c|c|c|c|c|}
\hline & 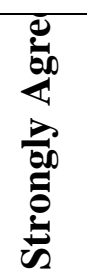 & 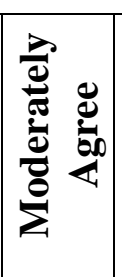 & ميّ & 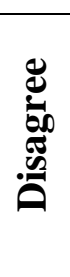 & 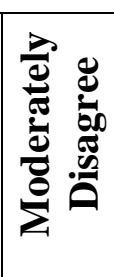 & 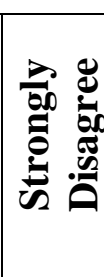 \\
\hline \multicolumn{7}{|c|}{ I prefer the following methods of advertisement for dairy programs: } \\
\hline 7. email & SA & MA & A & $\mathrm{D}$ & MD & SD \\
\hline 8. mail & SA & MA & A & $\mathrm{D}$ & MD & SD \\
\hline 9. pamphlets & SA & MA & A & $\mathrm{D}$ & MD & SD \\
\hline 10. fliers & SA & MA & A & $\mathrm{D}$ & $\mathrm{MD}$ & SD \\
\hline 11. word of mouth & SA & MA & A & $\mathrm{D}$ & $\mathrm{MD}$ & SD \\
\hline 12. exhibits & SA & MA & A & $\mathrm{D}$ & $\mathrm{MD}$ & SD \\
\hline 13. radio & SA & MA & A & $\mathrm{D}$ & MD & SD \\
\hline 14. farm visits & SA & MA & A & $\mathrm{D}$ & MD & SD \\
\hline 15. television & SA & MA & A & $\mathrm{D}$ & $\mathrm{MD}$ & SD \\
\hline 16. internet & SA & MA & A & $\mathrm{D}$ & MD & SD \\
\hline 17. newspaper & SA & MA & A & $\mathrm{D}$ & $\mathrm{MD}$ & SD \\
\hline 18. Other (please specify): & SA & MA & A & $\mathrm{D}$ & MD & SD \\
\hline
\end{tabular}




\begin{tabular}{|c|c|c|c|c|c|c|}
\hline & 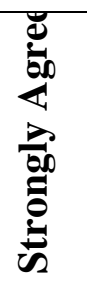 & 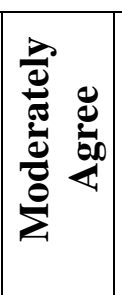 & 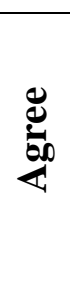 & 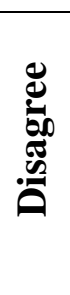 & 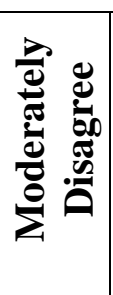 & 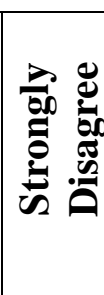 \\
\hline \multicolumn{7}{|c|}{ I prefer the following teaching methods at dairy programs: } \\
\hline 19. demonstrations & SA & MA & A & $\mathrm{D}$ & $\mathrm{MD}$ & SD \\
\hline 20. using computer software & SA & MA & A & $\mathrm{D}$ & MD & SD \\
\hline 21. lectures & SA & MA & A & $\mathrm{D}$ & $\mathrm{MD}$ & SD \\
\hline 22. pamphlets & SA & MA & A & $\mathrm{D}$ & $\mathrm{MD}$ & SD \\
\hline 23. internet & SA & MA & A & $\mathrm{D}$ & $\mathrm{MD}$ & SD \\
\hline 24. videos/DVDs & SA & MA & A & $\mathrm{D}$ & $\mathrm{MD}$ & SD \\
\hline 25. audio cassettes/CDs & SA & MA & A & $\mathrm{D}$ & MD & SD \\
\hline 26. group work & SA & MA & A & $\mathrm{D}$ & MD & SD \\
\hline 27. fact sheets & SA & MA & A & $\mathrm{D}$ & $\mathrm{MD}$ & SD \\
\hline 28. books & SA & MA & A & $\mathrm{D}$ & MD & SD \\
\hline 29. Other (please specify): & SA & MA & A & D & MD & SD \\
\hline
\end{tabular}




\begin{tabular}{|c|c|c|c|c|c|c|}
\hline & 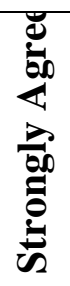 & 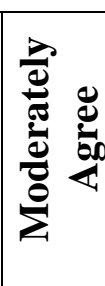 & 岕 & 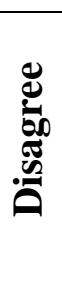 & 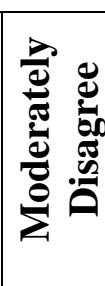 & 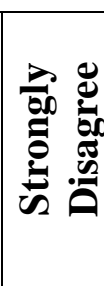 \\
\hline \multicolumn{7}{|c|}{ I am interested in dairy programs related to: } \\
\hline 30. Dairy Nutrition & SA & MA & A & $\mathrm{D}$ & MD & SD \\
\hline 31. Heifer Management & SA & MA & A & $\mathrm{D}$ & MD & SD \\
\hline 32. Financial Management & SA & MA & A & $\mathrm{D}$ & MD & SD \\
\hline 33. Forage Production & SA & MA & A & $\mathrm{D}$ & MD & SD \\
\hline 34. Milking Management & SA & MA & A & $\mathrm{D}$ & MD & SD \\
\hline 35. Herd Health & SA & MA & A & $\mathrm{D}$ & MD & SD \\
\hline 36. Reproduction & SA & MA & A & $\mathrm{D}$ & MD & SD \\
\hline 37. Nutrient Management & SA & MA & A & $\mathrm{D}$ & MD & SD \\
\hline 38. Barn Construction & SA & MA & A & $\mathrm{D}$ & MD & SD \\
\hline 39. Record Keeping & SA & MA & A & $\mathrm{D}$ & MD & SD \\
\hline 40. Dairy Quality Assurance & SA & MA & A & $\mathrm{D}$ & MD & SD \\
\hline 41. Other (please specify): & SA & MA & A & $\mathrm{D}$ & MD & SD \\
\hline
\end{tabular}


Instructions: Answer the following questions to the best of your ability.

42. Where do you go to get answers to your dairy production questions (Rank with 1 being the most used, 2 being the second most used and 3 being the third most used)

a. County Extension Agent

b. Farm Nutritionist

c. Veterinarian

d. Neighbor

e. Farm Store Employee

f. Other:

43. How many dairy extension programs do you attend per year?

a. 0

b. $1-2$

c. $3-4$

d. 5 or more

44. How many head of dairy cattle do you have on your farm?

a. $1-20$

b. $21-40$

c. $41-60$

d. $61-80$

e. $81-100$

f. 101 or more

45. What is your age range?

a. Younger than 20 years

b. 20-29 years

c. 30-39 years

d. 40-49 years

e. 50-59 years

f. 60 or older years 


\section{Comments:}

If you have any questions regarding this survey feel free to email me at cnelso17@mix.wvu.edu.

Thank yow for taking the lime and effort to complete this survey. 
APPENDIX H

Dairy Producer Open-ended Responses 


\section{Open-ended Responses}

Question 1: "My County Extension Office offers programs in dairy production” Responses:

Don’t Know

Question 2: "My County Extension Office is able to answer most of my questions about dairy production”

Responses:

I don’t ask a lot

Never asked him

Don’t know (2)

Question 3: “My County Extension Office returns my calls/emails quickly and efficiently.”

\section{Responses:}

I don’t use emails (2)

Don’t have email

Don’t know

Question 4: "My County Extension Office is a reliable source for my dairy questions.”

Responses:

I don't use CE that much

Don't use them

Don’t know (2)

Question 5: "I am willing to attend extension programs offered by my county.” 


\section{Responses:}

If I like them

No

Question 6: "I am willing to accept and use new practices learned at Extension programs.”

Responses:

All depends what they are

Don’t Know

Question 7: "I prefer the use of email as a method of advertisement for dairy programs.”

Responses:

Don't Use

Don’t Have (2)

Question 12:"I prefer exhibits as an advertisement method for dairy Extension programs.”

Responses:

Don’t Go (2)

Question 13:“I prefer radio as a method of advertisement for dairy Extension programs.”

Responses:

Don’t Have (2)

Question 15: "I prefer television as a method of advertisement for dairy programs.”

Responses: 


\section{Don't Have (2)}

Question 16: "I prefer Internet as a method of advertisement for dairy programs.”

\section{Responses:}

Don’t Have (3)

Question 17: "I prefer the use of newspaper as a method of advertisement for dairy programs.”

Responses:

Daily not for farming

Lancaster Farming Newspaper

Question 18: “I prefer other methods of advertisement for dairy programs”

Responses:

Farm Magazines

Lancaster Farming

Farm Paper - Lancaster Farming/Farmshine

Personally Call

Question 29: "I prefer other teaching methods at dairy programs"

Responses:

Hands on when possible

On farm tours

Monthly newsletter

Question 41: “I am interested in other dairy programs.”

Responses:

Hoof trimming/Care 
People Management

Programs for core credits pesticide license

New Practices

Proving conventional milk is as healthy as “organic” milk

Passing on the farm to the next generation

Transition-dry cow management

Question 42: "Where do you go to get answers to your dairy production

questions?”

Responses:

We are customers of Agri King Inc. which is an animal nutrition co., and has

veterinarians and nutritionists on call for problem solving. They have provided

help for over 25 years. They are based at Fulton, Illonois.

Or Friend

Magazines (2)

Brother

Retired Farmer

Farm Publications

Dairy Consultant

Internet

Employees

God

Internet

Question 44: “How many head of dairy cattle do you have on your farm?” 


\section{Responses:}

Cows and Heifers

Milking

Question 45: "What is your age range?"

Responses:

Partner 1 is 20-29 and Partner 2 is 50-59

This farm is a partnership. Partner 2 is 20-29 
APPENDIX I

Dairy Producer Comments 


\section{Comments}

Responses:

Questions 1-4 were not answered because neither my husband nor myself were sure we had a dairy agent and/or programs in our county office. Questions 5 \& 6 reflect our answers if we had an active extension office. We would be more involved and interested in what is going on if we knew what our county was doing.

Sorry I couldn't answer better. I don't even know where the County Extension Office is or what their job is. I grew up on a dairy farm so I learned hands on. I don't think I ever had any contract with County Extension Office.

The letters N/A were not available to be circled. The scale was not intuitive to me because "agree" implies a definite position, which would fit between "strongly" and "moderately". Likewise for the disagree side.

Question 2-4 I could not answer because I never called the County Extension Agent!

If we go to county agent for advice it is from our neighboring county (Bradford-great guy) agent, not our own county agent

There is no Dairy Extension Agent in my county anymore

Dairy does not have an agent specifically covering our county alone. We are part of a Regional Dairy Team of Extension Agents. 
I do read the reading material I get sent in the mail from the Extension Office. I think Brian Kelly does a good job.

County Extension Agents are expected to cover too many counties. As the dairy business gets more technical \& difficult we have less opportunity to know our Extension Agent. We must travel too many miles to take part in educational meetings.

I don't go to dairy programs.

When I started farming in the 1980's I went to several extension meetings. As time moved on, industry started offering better speakers, and I started attending them. Also our former extension agent retired, whom I knew well and the two new guys I never learned to know. So my main contact now is through written newsletters.

Extension service has not been a very active part of our program for some time.

Our Extension Agent is only on the band wagon of whatever practices that the Land Grant University is pushing at the time. If it is something new that they don't have an interest in then you cannot get any info or help from them. They seem to do just what they have to so they can collect the Friday paycheck.

I do not use the services offered by the county extension office

Keep up the good work. 
Extension meeting cost too much or I would attend more often.

I like the farm meetings and learning work-learning-sessions.

Dairy extension people have opportunities to help educate. However it seems that all they do is to repeat the same programs over each year.

No email, No Internet

I personally make my living from my dairy cows. I look at my cattle like they are my boss but my best friend also. Reaction toward animal cruelty can go overboard but some manners should be pushed on animal welfare. I get disgusted when I see cattle living in the woods during wind and 0 degree temps or lying in manure. If you don't have in your heart to put them out of their misery or pain in event of illness or injury and don't have the heart to provide good cover and feed you shouldn't have animals in the first place.

When my husband and his partner started farming in 1982 they attended all the Dairy Days and Crop Days and valued the information they received. In 1993 we bought out the partnership and time became more of a factor. All the dairy programs you listed were important at one time or another but for now he rarely attends any programs. Whenever I stop in@ the Farm and Home Center, everyone from all the agencies are very helpful.

Wheras ye know not what shall be the morrow. For what is your life? It is even a vapour that appearath for a little time and then vanisheth away. James 4:14. Where will you spend eternity? For more information call. 
Sold cows. Not farming. Selling farm

I am no longer in dairy or an Ag business. Please take me off your mailing list.

Don't Bother Me.

Don't send more of these copies. 
May 2007

May 2008

\section{Professional Experience:}

\section{Education:}

Experience:
(19) 2007

May 2007

\author{
VITA \\ Carrie B. Nelson
}

May 2008

September 2004-

August 2007-May

2008
Bachelor's of Science

Animal Sciences

The Pennsylvania State University

University Park, Pennsylvania

Master's of Science

Agricultural and Extension Education

West Virginia University

Morgantown, West Virginia

Research Assistant

Dairy and Animal Science

College of Agricultural Sciences

The Pennsylvania State University

University Park, Pennsylvania

Graduate Assistant

Agriculture and Extension Education

Davis College of Agriculture, Forestry, and Consumer Sciences

West Virginia University

Morgantown, West Virginia 